\title{
Applying Cost-Benefit to Past Decisions: Was Environmental Protection Ever a Good Idea?
}

\author{
Lisa Heinzerling \\ Georgetown University Law Center, heinzerl@law.georgetown.edu \\ Frank Ackerman \\ Tufts University \\ Rachel Massey \\ Tufts University
}

This information or any portion thereof may not be copied or disseminated in any form or by any means or downloaded or stored in an electronic database or retrieval system without the express written consent of the American Bar Association.

This paper can be downloaded free of charge from:

https://scholarship.law.georgetown.edu/facpub/323

57 Admin. L. Rev. 155-192 (2005)

This open-access article is brought to you by the Georgetown Law Library. Posted with permission of the author. Follow this and additional works at: https://scholarship.law.georgetown.edu/facpub

Part of the Administrative Law Commons, and the Environmental Law Commons 


\title{
GEORGETOWN LAW Faculty Publications
}

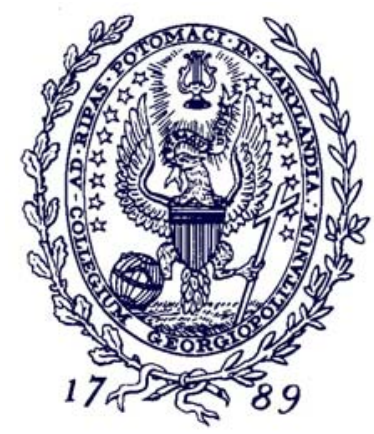

April 2010

\section{Applying Cost-Benefit to Past Decisions: Was Environmental Protection Ever a Good Idea?*}

57 Admin. L. Rev. 155-192 (2005)

\section{Lisa Heinzerling}

Professor of Law

Georgetown University Law Center

heinzerl@law.georgetown.edu

\section{Frank Ackerman}

Global Development \& Environmental Institute

Tufts University

frank.ackerman@tufts.edu

\author{
Rachel Massey \\ Tufts University \\ rachel.massey@tufts.edu
}

Global Development \& Environmental Institute

This paper can be downloaded without charge from:

Scholarly Commons: http://scholarship.law.georgetown.edu/facpub/323/

Posted with permission of the author

* This information or any portion thereof may not be copied or disseminated in any form or by any means or downloaded or stored in an electronic database or retrieval system without the express written consent of the 


\title{
APPLYING COST-BENEFIT TO PAST DECISIONS: WAS ENVIRONMENTAL PROTECTION EVER A GOOD IDEA?
}

\author{
FRANK ACKERMAN, LISA HEINZERLING \& RACHEL MASSEY*
}

\section{TABLE OF CONTENTS}

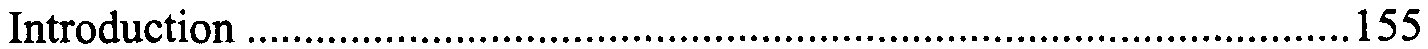

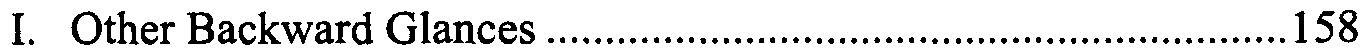

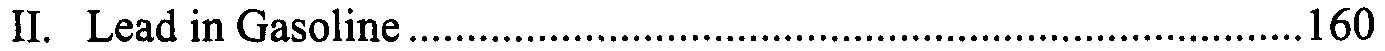

III. Damming the Grand Canyon ........................................................172

IV. Vinyl Chloride in the Workplace ................................................182

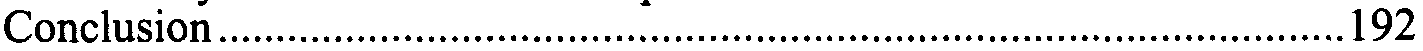

\section{INTRODUCTION}

One of the most contentious issues in contemporary debates over environmental policy is whether regulators should use cost-benefit analysis in evaluating their decisions. Cost-benefit analysis requires that the costs and benefits of a proposed course of action (including benefits such as saving human lives and protecting human health) be quantified and then translated into dollar terns. Cost-benefit analysis of proposed regulations is said to be necessary in order to avoid adopting inefficient rules that would impose ruinous economic costs. ${ }^{1}$ Such analysis is also said, in theory, to be a neutral, objective method of evaluating policies and offering transparent judgments on the merits of a proposal. ${ }^{2}$

* Frank Ackerman is an environmental economist and research director of the Global Development and Environment Institute (GDAE) at Tufts University. Lisa Heinzerling is a Professor of Law at the Georgetown University Law Center. Rachel Massey is a Research Associate at GDAE. The authors are grateful to Thomas Henry, Gabrielle Herman, Jennifer Lappin, Trevor Wiessmann, and Danielle Woods for research assistance.

1. Frank ACKerman \& Lisa Heinzerling, Priceless: On KNOWINg the Price of EVERYTHING AND THE VALUE OF NOTHING 59 (The New Press 2004).

2. Robert W. Hahn \& Cass R. Sunstein, $A$ New Executive Order for Improving Federal Regulation? Deeper and Wider Cost-Benefit Analysis, 150 U. PA. L. REV. 1489, 1504-05 (2002). 
Fans of cost-benefit analysis who argue that this technique is a neutral tool for evaluating public policies must be able to show that the analysis is not simply a one-way street to deregulation. Thus, in evaluating their arguments, it is instructive to ask a simple question: If this analytical device had been applied in the 1970s and earlier, would it have endorsed the early successes of health and environmental regulation? Or would it have resulted in negative judgments wherever and whenever it was applied? The latter is the more accurate answer, with just a few exceptions, as we demonstrate in this Article.

The first wave of modern environmental protection, beginning in the $1960 \mathrm{~s}$ and 1970s, cleaned up the air and water, protected fragile ecosystems, and achieved great gains in public health-without reliance on cost-benefit analysis, and clearly without destroying the economy. ${ }^{3}$ Why can't we continue to make environmental policy this way? Advocates of cost-benefit analysis must believe that times have changed. Perhaps past environmental policies have already hit the easy targets, where the need for regulation was obvious; in the standard metaphor, all the low-hanging fruit might already have been picked.

If this were the case, the environmental regulations of the past should easily pass a cost-benefit test. If today's methods of cost-benefit analysis had been applied in the past, would it have given its blessing to the early regulations which now look so successful in retrospect? The answer is no. This conclusion derives from three case studies: the removal of lead from gasoline in the 1970s and 1980s, the decision not to dam the Grand Canyon for hydroelectric power in the 1960 s, and the strict regulation of workplace exposure to vinyl chloride in 1974. The technique would have gotten the answer wrong in all three cases. Each case study illustrates, in a different manner, the damage that cost-benefit analysis could have done in the past, had it played the central role that is proposed for it today. The problems with cost-benefit analysis of regulations lie deep within the methodology; ${ }^{4}$ it would not have done any better a generation ago than it does now.

We have argued elsewhere that environmental protection does not cause economic harm, ${ }^{5}$ and that the widely cited "evidence" of huge regulatory costs is erroneous on several grounds. ${ }^{6}$ Indeed, the entire cost-benefit

3. See generally Thomas O. McGarity et Al., Sophisticated Sabotage: The INTELlECTUAL GAMES USED to SUbVERT RESPONSIBLE REgUlation 17-18 (Environmental Law Institute 2004).

4. ACKERMAN \& HEINZERLING, supra note 1 .

5. See Frank Ackerman \& Rachel Massey, Prospering With Precaution, at http:// www.ase.tufts.edu/gdae/publications/articles_reports/PrecautionAHTAug02.pdf (2002) (and sources cited therein).

6. ACKERMAN \& HEINZERLING, supra note 1; see also Lisa Heinzerling \& Frank Ackerman, The Humbugs of the Anti-Regulatory Movement, 87 CORNELL L. REV. 648 (2002); Lisa Heinzerling, Regulatory Costs of Mythic Proportions, 107 YALE L.J. 1981 
project is problematic and incoherent. In a cost-benefit analysis, analysts add up the costs (for example, for pollution control equipment), and compare them to estimates of the monetary value of the resulting benefits (for example, the dollar value of the deaths and diseases avoided by reducing pollution). This effort routinely fails. Although the benefits of health and environmental protection are vitally important, this effort routinely fails because the pecuniary value of the deaths and diseases avoided by reducing pollution cannot be meaningfully expressed in monetary terms. In a word, the benefits are priceless. ${ }^{7}$ The cost-benefit calculation's attempt to assign monetary values distorts, misrepresents, and narrows the priceless values of life, health, and nature, and belittles the widespread concern for the well-being of future generations.

In practice, therefore, cost-benefit analysis is an opaque and technically intricate process accessible only to experts, and one that all too frequently recommends rejection of sensible policies, on the grounds that their costs exceed economists' estimates of their benefits. In the hands of John Graham, the Bush Administration's "regulatory czar" at the Office of Information and Regulatory Affairs (OIRA), cost-benefit analysis has been used as a powerful weapon against regulatory initiatives proposed by the Environmental Protection Agency (EPA) and other agencies. ${ }^{8}$

In this Article, however, we do not mount a critique from outside the technique of cost-benefit analysis. Instead, we examine an argument that proponents of cost-benefit analysis have offered as a linchpin of the case for cost-benefit: that this technique is neither anti- nor pro-regulatory, but rather a neutral tool for evaluating public policy. In making this argument, these proponents have often invoked the use of cost-benefit analysis to support previous regulatory decisions (their favorite example involves the phase down of lead in gasoline, which we shall shortly discuss) as a sign that this technique can be used to support as well as to undermine protective regulation. As we demonstrate, however, cost-benefit analysis would have stood as an obstacle to early regulatory successes. Before turning to the various case studies illustrating this point, we first take a brief look at previous efforts to undertake retrospective cost-benefit analyses of important regulatory achievements.

(1998).

7. ACKERMAN \& HEINZERLING, supra note 1.

8. See Ellen Nakashima, For Bush's Regulatory 'Czar,' The Equation is Persuasion, WASH. POST, May 10, 2002, at A35 (noting that the Office of Information and Regulatory Affairs (OIRA) signed off on a proposed rule allowing companies to dump waste from coalmining operations into rivers and streams). 


\section{OTHER BACKWARD GLANCES}

We are not the first to explore cost-benefit analyses of past regulatory decisions. Some retrospective cost-benefit studies have supported environmental protection, while some commentators have suggested that such studies show that cost-benefit analysis contains no systematic bias against environmental regulation. ${ }^{9}$ We believe that the wrong lesson has been drawn from these studies, exaggerating the prospects for cost-benefit analysis to support environmental protection in the future.

One widely cited retrospective study is a multi-year, peer-reviewed study by the Environmental Protection Agency (EPA) of the first 20 years of the Clean Air Act (1970-90), published in 1997. This study found benefits from air pollution regulation equal to about forty times the costs. ${ }^{10}$ More recently, annual analyses by OIRA have estimated, retrospectively, the monetized costs and benefits of major regulations of the recent past. The OIRA report for 2004 estimates that major EPA regulations adopted from 1993 to 2003 imposed $\$ 22-24$ billion in costs, and yielded \$38-132 billion in benefits. ${ }^{11}$ OIRA cautioned against getting too excited about these upbeat numbers:

The majority of the large estimated benefit of EPA rules is attributable to reduction in public exposure to a single air pollutant: fine particulate matter. Thus, the favorable benefit-cost results for EPA regulation should not be generalized to all types of EPA rules or to all types of clean-air rules. ${ }^{12}$

In general, as OIRA suggests, cost-benefit analysis tends to endorse efforts to reduce a handful of high-volume air pollutants. The huge estimated benefits of these measures account for EPA's favorable analysis of the Clean Air Act, as well as OIRA's numbers for EPA regulations as a whole. Look beyond the criteria air pollutants, and the evidence becomes quite sparse for cost-benefit analysis supporting environmental protection. Furthermore, Graham's office has worked to reduce the apparent benefits of controlling even these widespread and harmful air pollutants. ${ }^{13}$

Moreover, the EPA's positive cost-benefit analysis would not have been

9. See Kerry Smith, Choice Cuts, ThE AMERICAN ProsPeCt ON-LINE (2004), available at http://www.prospect.org/web/page.ww?section=root\&name=ViewWeb\&articleld $=7696$ (last visited Oct. 31, 2004).

10. See EnVironmental Protection Agency, Report to Congress: The Benefits AND COSTS OF THE CLEAN AIR ACT 1970-1990 (1997).

11. See Office of Management and Budget, Office of Information and Regulatory Affairs, Informing Regulatory Decisions: 2004 Draft Report to Congress on the Costs and Benefits of Federal Regulations and Unfunded Mandates on State, Local, and Tribal Entities (2004), tbl.2 [hereinafter Informing Regulatory Decisions], at http:// www.whitehou se.gov/omb/inforeg/regpolreports_congress.html.

12. Id. at 7.

13. See Neil Shah, OMB Official Highlights EPA Problems in Assessing Benefits of Air Rules, INSIDE EPA, June 18, 2004. 
possible at the time the Clean Air Act protections were put in place. A huge proportion of the benefits found by the EPA were due to regulating emissions of fine particles in the air - but the full magnitude of the harm done by such particles was not known for many years after the Act was first implemented. ${ }^{14}$ If a favorable cost-benefit analysis of the Clean Air Act's regulation of fine particles had been required before adoption of the Act, the result would have been the same as in the lead and vinyl chloride case studies we examine in this paper: the Act's requirements would have been rejected for lack of sufficiently definitive data.

In another frequently cited study, economist Richard Morgenstern assembled twelve case studies of regulations where EPA's economic analyses played an important role. ${ }^{15}$ His case studies, written by analysts who played a major role in the regulatory process, were chosen to highlight the positive contribution of EPA's economic analyses (through the first term of the Clinton administration).

Morgenstern's case studies divide naturally into three groups. In four cases, no monetization of benefits was attempted, so no formal quantitative comparison of costs and benefits was possible. ${ }^{16}$ In four cases, some benefits were monetized, but the regulatory decision was based on technology standards or other criteria, and did not maximize net benefits. ${ }^{17}$ In the remaining four cases, cost-benefit analysis appeared to endorse the final decision, weakly in one case and strongly in the other three. In two cases, however, the cost-benefit analysis was not completed until after a decision had been made on other grounds, so it was not a factor in the regulatory process. ${ }^{18}$ The two cases where cost-benefit analysis was a crucial input into decisionmaking both involved lead pollution. ${ }^{19}$ The

14. See Environmental Protection Agency, Particulate Matter (PM) Research, at http:// www.epa.gov/pmresearch (last visited Oct. 31, 2004).

15. See ECONOMIC ANALYSES AT EPA: AsSESSING Regulatory IMPACT (Richard D. Morgenstern ed., Resources for the Future 1997) [hereinafter ECONOMIC ANALYSES AT EPA].

16. See, e.g., Eloise Trabka Castillo et al., Great Lakes Water Quality Guidance, in ECONOMIC ANALYSES AT EPA, supra note 15, at 419-54; Mahesh Podar et al., Municipal Sewage Sludge Management, in ECONOMIC ANALYSES AT EPA, supra note 15, at 365-90; Todd Ramsden, Vehicle Inspection/Maintenance, in ECONOMIC ANALYSES AT EPA, supra note 15, at 333-63; Robert C. Anderson and Richard A. Rykowski, Reformulated Gasoline, in ECONOMIC ANALYSES AT EPA, supra note 15, at 391-418.

17. See, e.g., Christine M. Augustyniak, Asbestos, in ECONOMIC ANALYSES AT EPA, supra note 15, at 171-203; Peter Caulkins and Stuart Sessions, Water Pollution and the Organic Chemicals Industry, in ECONOMIC ANALYSES AT EPA, supra note 15, at 87-130; Leland Deck, Visibility at the Grand Canyon and the Navajo Generating Station, in ECONOMIC ANALYSES AT EPA, supra note 15, at 267-301; James K. Hammitt, StratosphericOzone Depletion, in ECONOMIC ANALYSES AT EPA, supra note 15, at 131-69.

18. See Sara Rasmussen, Municipal Landfill Management, in ECONOMIC ANALYSES AT EPA, supra note 15, at 233-66; see also Louis P. True Jr., Agricultural Pesticides and Worker Protection, in ECONOMIC ANALYSES AT EPA, supra note 15, at 303-32.

19. See Ronnie Levin, Lead in Drinking Water, in ECONOMIC ANALYSES AT EPA, supra note 15, at 205-32; see also Albert L. Nichols, Lead in Gasoline, in ECONOMIC ANALYSES 
famous cost-benefit analysis of removing lead from gasoline is the subject of one of our case studies in this Article. The regulation of lead in drinking water was almost a sequel to lead in gasoline, addressed by the same analysts using much of the same data, just a few years later.

Like Morgenstern, we find that cost-benefit analysis played a minor role in the regulatory processes we evaluate. Furthermore, requiring a positive cost-benefit analysis before adopting regulations, as currently advocated, would have prevented some of the great policy successes of the past decades. Our first example involves removing lead from gasoline.

\section{LEAD IN GASOLINE}

Whenever proponents of cost-benefit analysis seek to show how it can be used to protect the environment, they cite the example of EPA's phase down of lead in gasoline in the 1980s. ${ }^{20}$ With this rule, the EPA ordered a large reduction of levels of lead in gasoline. The EPA's decision was supported by an extensive cost-benefit analysis, which demonstrated that the benefits of the phase down greatly outweighed the economic costs. ${ }^{21}$ Such notable regulatory scholars as John Graham, ${ }^{22}$ Robert Hahn, ${ }^{23}$ Richard Stewart, ${ }^{24}$ Cass Sunstein, ${ }^{25}$ and Jonathan Wiener ${ }^{26}$ have pointed to the influence of cost-benefit analysis on the 1980s-era lead phase down as evidence of the evenhandedness of this analytical framework.

However, that cost-benefit analysis only appeared in the last act of a long drama. To summarize the plot in brief: leaded gasoline, introduced in the 1920s despite clear early warnings of severe health hazards, dominated the market for fifty years. ${ }^{27}$ Regulations removing most of the lead from gasoline were finally adopted in the 1970s, and upheld by the courts in a landmark legal decision. ${ }^{28}$ The 1970 s regulation was adopted on a

AT EPA, supra note 15 , at $49-86$.

20. See infra notes 22-25.

21. Nichols, supra note 19.

22. See George M. Gray, Laury Seligman \& John D. Graham, The Demise of Lead in Gasoline, in THE GREENING OF INDUSTRY: A RISK MANAGEMENT APPROACH (John D. Graham \& Jennifer Kassalow Hartwell eds., Harvard Univ. Press 1997).

23. See Hahn \& Sunstein, supra note 2, at 1523.

24. See Bruce A. Ackerman \& Richard B. Stewart, Reforming Environmental Law, 37 StaN. L. REV. 1333, 1363 (1985); see also Richard B. Stewart, A New Generation of Environmental Regulation?, 29 CAP. U. L. REV. 21, 75 n.45 (2001).

25. Cass R. Sunstein, Cognition and Cost-Benefit Analysis, 29 J. LEGAL STUD. 1059, 1071 (2000); see also Cass R. Sunstein, In Praise of Numbers: A Reply, 90 GEO. L.J. 2379, $2384(2002)$.

26. Jonathan B. Wiener, Whose Precaution After All?, 13 DUKE J. COMP. \& INT'L L. 207, 223 (2003).

27. For a comprehensive history of the marketing of, scientific research on, and eventual regulation of lead in gasoline, see GERALD MARKOWITZ \& DAVID ROSNER, DECEIT AND DENIAL: The DeAdLy Politics OF INDUSTRIAL Pollution (Univ. of Cal. Press 2002).

28. See Ethyl Corp. v. EPA, 541 F.2d 1 (D.C. Cir. 1976). 
precautionary basis without reliance on cost-benefit analysis, under the Clean Air Act's provision giving the EPA the authority to "control or prohibit" fuel additives if they "will endanger the public health or welfare." 29 The EPA's new rule was effective in rapidly lowering blood lead levels. One convenient side effect was the creation of the data that later allowed a cost-benefit analysis, in the 1980s, to confirm the wisdom of staying the course and even going further to remove the last bit of lead from fuel. Thus, the cost-benefit analysis of the 1980s phase down of lead in gasoline would not have been possible in the absence of the more important 1970s-era regulation-which was not itself based on cost-benefit analysis. Had we waited in the 1970s, as some argue we should do in policy disputes today, for cost-benefit analysis to show us the way, we might still be waiting now.

\section{Lead Comes Knocking}

Lead was introduced into gasoline in the 1920s, at a time of fierce competition in the growing market for automobiles. Then as now, two of the features that could set one car apart from another were power and speed. Increasing compression in the car engine increases power and speed, but it can also increase "knocking," or the loss of power accompanied by the familiar popping sound of very old cars. ${ }^{30}$

General Motors (GM) set out to find an anti-knock compound that would allow its cars to increase their power and speed without increasing knocking. Thomas Midgley Jr., an engineer in a GM research lab, tested numerous substances for this purpose-including tetra ethyl lead (TEL). Pursuing the enticing possibility of a substance one could patent (and thus corner the market in), Midgley shunted to the side another potential antiknock compound, ethanol, in favor of TEL. ${ }^{31}$ As Jamie Lincoln Kitman states in his indispensable account of the development of TEL, "any idiot with a still" could make ethanol, which made it far less attractive as an antiknock compound to the profit-conscious GM. ${ }^{32}$

At the time, GM was controlled by Pierre du Pont, and eventually

29. See 42 U.S.C. $\$ 7545(\mathrm{c})(1)(\mathrm{A})(2000)$. This provision was amended in 1977 to allow the agency to regulate fuel additives whenever they "may reasonably be anticipated to endanger the public health or welfare." Id.

30. See Herbert L. Needleman, History of Lead Poisoning in the World, at http://www.leadpoison.net/general/history.htm (1999) (last visited Oct. 31, 2004).

31. Midgley also brought the world another famous compound: chlorofluorocarbons, or CFCs, later implicated in ozone depletion and banned in a global treaty about the same time lead was banned in gasoline in the United States. See Jamie Lincoln Kitman, The Secret History of Lead, THE NATION, Mar. 20, 2000, at 5, available at http://www.thenation. com/doc.mhtml?

$\mathrm{i}=20000320 \& \mathrm{~s}=$ kitman (last visited Jan. 8,2005 ).

32. Id. at 6 . 
teamed with Standard Oil of New Jersey to form a new company-the Ethyl Corporation-to market TEL. ${ }^{33}$ Even before this development, plants in Ohio and New Jersey were busy making the chemical. The problems started immediately. Within the first month of producing TEL, a worker died at the Ohio plant. ${ }^{34}$ Eventually, fifteen workers died, and hundreds more fell ill. $^{35}$ Workers called one production facility in New Jersey the "House of Butterflies" because high lead exposure caused hallucinations which led workers to swat imaginary insects off of their bodies. $^{36}$

The Surgeon General convened a panel of experts to study the potential health effects of TEL, but gave them only seven months in which to come to a conclusion. ${ }^{37}$ Ethyl voluntarily suspended production of TEL while the Surgeon General's committee did its work. ${ }^{38}$ The committee did find more lead in the blood of people occupationally exposed to lead-such as chauffeurs and garage men-but was unable to find health effects from these higher exposures within the committee's tight timeline. ${ }^{39}$ The committee ultimately found "no good grounds for prohibiting the use of ethyl gasoline ... as a motor fuel, provided that its distribution and use are

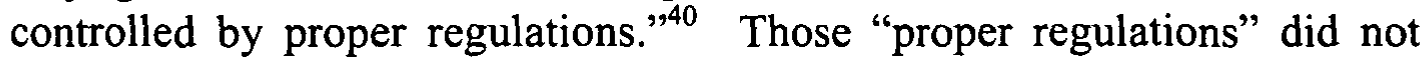
appear until almost fifty years later. The panel also issued the following cautionary note:

It remains possible that, if the use of leaded gasolines becomes widespread, conditions may arise very different from those studied by us which would render its use more of a hazard than would appear to be the case from this investigation. Longer experience may show that even such slight storage of lead as was observed ... [among humans] in these [1925] studies may lead eventually to recognizable lead poisoning or to chronic degenerative diseases of a less obvious character .... The vast increase in the number of automobiles throughout the country makes the study of all such questions a matter of real importance from the standpoint of public health. ${ }^{41}$

It would be many years, however, before anyone took up the issue again. Within months of the committee's report, TEL was back on the market.

33. Id. at 8 .

34. Id. at 9 .

35. Needleman, supra note 30.

36. Id.

37. Kitman, supra note 31 .

38. Id.

39. See Jack Lewis, Lead Poisoning: A Historical Perspective, EPA J. (May 1985), available at http://www.epa.gov/history/topics/perspect/lead.htm (last visited Oct. 31, 2004) (noting that the committee argued that "seven months was 'not sufficient' ... 'to produce detectable symptoms of lead poisoning"').

40. Id.

41. Id. 


\section{The "Kehoe Rule"}

In a 1922 letter to his brother Irénée (the head of DuPont Chemical), GM chief Pierre du Pont described TEL as "a colorless liquid of sweetish odor, very poisonous if absorbed through the skin, resulting in lead poisoning almost immediately." 42 Yet for the next fifty years, the makers of leaded gasoline would deny this basic fact: lead is a poison. When faced with the warnings of public health authorities about the potentially dire effects of spewing lead into the atmosphere from millions of automobiles, the industry had a simple response: prove it. ${ }^{43}$

It was difficult, however, to prove that the day-to-day, low-level exposures to lead caused by leaded gasoline hurt people. The kinds of health effects we now know come from lead - reduced learning capacity, neurological disorders, and high blood pressure - are quite common, and have several potential causes which make it difficult to determine which portion of these effects is due to lead. Thus, although the U.S. government had suspected the risks of adding lead to gasoline from the very beginning, it would not seriously try to regulate leaded gasoline until lead had been pouring from almost every automobile in the country for half a century.

The "prove it's dangerous" approach was dubbed by Jamie Kitman as the "Kehoe Rule" after Robert Kehoe, the medical director for the Ethyl Corporation, who pursued and perfected the approach during decades of asserting the safety of leaded gasoline. The Kehoe Rule was particularly effective in silencing dissent because most of the lead-related research conducted in the middle part of the twentieth century was funded by the interested industries themselves. ${ }^{44}$ Kehoe maintained that the blood lead levels of the people most exposed to lead-those who were exposed on the job-gave little cause for alarm because these levels were not a great deal higher than the blood lead levels of the presumably unexposed "control" population. $^{45}$

The idea that high levels of lead in the blood were natural, normal, and benign got its comeuppance from an unlikely source: a geochemist studying the age of the Earth. Clair Patterson's research on this subject involved precise chemical analysis of ocean sediments and archaeological material, which incidentally established that the contemporary body burden of lead was far above pre-industrial levels. ${ }^{46}$ His findings directly refuted

42. Kitman, supra note 31 .

43. Id.

44. See id.

45. See Colleen F. Moore, Silent Scourge: Children, Pollution, and Why SCIENTISTS DiSAGreE 18 (Oxford Univ. Press 2003) (revealing that Kehoe's control population were people from a remote area of Mexico who used tableware made with lead glazes and therefore had high levels of lead in their blood).

46. See Clair C. Patterson, Contaminated and Natural Lead Environments of Man, in 11 
Kehoe and the lead industry's claim that the blood lead levels prevailing in the United States were natural.

Like other scientists who dared to challenge the lead industry's story line, Patterson found himself at the receiving end of the industry's wrath and was materially (and adversely) affected by it. ${ }^{47}$ Nevertheless, scientific findings by Patterson and others had begun to chip away at the factual basis for the industry's longstanding denials of the potential dangers of leaded gasoline.

\section{Congress Acts}

With the passage of the federal Clean Air Act Amendments of 1970, the era of leaded gas finally began to draw to a close. The Act directed the brand new EPA to regulate fuel additives (of which lead was the most important) if either of two conditions was met. First, Congress directed the EPA to regulate a fuel additive if the agency found that it "will endanger the public health or welfare." 48 Second, the EPA was to do so if the additive would impair the performance of the pollution control devices that were also required by the amendments to the Act. ${ }^{49}$

A review of the legislative history leading to these developments shows considerable concern in Congress about the potential dangers of airborne lead. It also reveals, however, how keenly aware Congress was of the scientific uncertainty that continued to surround this issue. ${ }^{50}$ Perhaps it goes without saying that Congress performed no cost-benefit analysis of the consequences of its decision to require regulation of fuel additives; none would have been possible, given the lack of quantitative data on the health and welfare effects of leaded gasoline.

Within weeks of the adoption of the amendments, ${ }^{51}$ the EPA's first Administrator, William Ruckelshaus, declared that leaded gasoline endangered the public health and welfare, and impaired the performance of catalytic converters. Moreover, Ruckelshaus gave public notice that he intended to issue a regulation reducing allowable levels of lead in gasoline. $^{52}$

ARchives of ENVTL. Health 344, 358 (1965); see also Ignasi Casanova, Clair Patterson (1922-95), Discoverer of the Age of the Earth, in 1 INT'L MiCROBIOLOGY No. $1231,231-32$ (1998).

47. See Kitman, supra note 31 .

48. 42 U.S.C. $\S 7545(\mathrm{c})(1)(\mathrm{A})(1977)$.

49. See id.

50. S. REP. NO. 91-1196 at 7 (1970), reprinted in COMM. ON PUB. WORKS, 91 sT CONG., A LEGiSlative History OF THE CleAN AIR ACT AMENDMENTS OF 1970, at 407 (1974).

51. The Clean Air Act Amendments of 1970 were signed into law by President Nixon on December 31, 1970. Ruckelshaus issued his announcement on Jan. 27, 1971.

52. See Regulation of Fuel Additives, 36 Fed. Reg. 1486 (Jan. 30, 1971) (anticipating the general availability of lead-free gasoline by July 1, 1974). 
In 1972, the EPA proposed a significant reduction in the allowable levels of lead in gasoline, ${ }^{53}$ requiring removal of most of the lead within just a few years. The EPA also proposed to require the availability of at least one grade of unleaded gasoline. The EPA thought lead would damage the catalytic converters that were required in new cars in order to reduce other forms of harmful air pollution. ${ }^{54}$ In addition, the EPA thought that lead itself was a threat to public health. Although the EPA could not put exact numbers on the health effects caused by lead, it thought the existing scientific evidence was strong enough to justify strict limits on lead in gas. The agency stated that the then-existing levels of airborne lead were "associated with a sufficient risk of adverse physiologic effects to constitute endangerment of public health." 55 The EPA concluded that its proposals to regulate lead would "provide for the protection of health in major urban areas within the shortest time reasonably possible."

In 1973, the EPA responded to extensive public comments on leaded gasoline by retreating somewhat from the 1972 proposal. The agency extended the deadline for the reduction of lead in gasoline and changed the calculations used to demonstrate refineries' compliance with the agency's requirements. ${ }^{57}$ At the same time, the EPA also softened its earlier claims about the link between airborne lead levels and public health. The agency admitted that scientific findings suggesting a correlation between air lead levels and blood lead levels could not "be taken as conclusive evidence that airborne lead by itself is a current public health problem." EPA worried that airborne lead might be contributing to "excessive total lead exposures among the general urban population." 59

As noted above, in order to regulate lead in gasoline for purposes of protecting public health, Congress required the EPA to find only that lead will "endanger public health or welfare." ${ }^{, 60}$ The EPA was not required to perform a cost-benefit analysis of reducing lead in gasoline, and it did not do so. Indeed, in its 1973 proposal, the EPA admitted that "the benefits associated with the accelerated lead reduction have not been quantified."

53. See Lead and Phosphorus Additives in Motor Vehicle Gasoline, 37 Fed. Reg. 3882, 3883 (Feb. 23, 1972) (proposing a decrease in the amount of lead in gasoline from 2.0 grams of lead per gallon in January 1974 to 1.25 grams per gallon by January 1977).

54. See id. at 3882 (explaining that the converters under development are likely to be in general use if lead additives are controlled).

55. Id.

56. Id.

57. See Regulation of Fuels and Fuel Additives, 38 Fed. Reg. 1258, 1260 (Jan. 10, 1973) (proposing to defer the reduction schedule by one year).

58. Id. at 1259 .

59. Id.

60. 42 U.S.C. $\S 7545$ (c)(1)(A) (2000).

61. Regulation of Fuels and Fuel Additives, supra note 57. 
In December 1973, the EPA issued final regulations on the subject. ${ }^{62}$ Large refineries were required to remove roughly 80 percent of the prevailing (early 1970s) level of lead from gasoline by 1979, and small refineries had to meet the same target by $1982 .^{63}$ The agency explained:

[I]t is difficult, if not impossible, to establish a precise level of airborne lead as an acceptable basis for a control strategy .... [However,] [s]trong evidence existed which supported the view that through these routes [air and dust] airborne lead contributes to excessive lead exposure in urban adults and children. In light of this evidence of health risks, the Administrator concluded that it would be prudent to reduce preventable lead exposure. ${ }^{64}$

The EPA explained that it had extended the deadline for lead reduction from four to five years in order to "moderate the economic and technological impacts of the regulations during the period over which the reduction would be accomplished." The EPA continued: "[T]hough the benefits associated with the ... lead reductions have not been quantified, the Administrator has concluded that this approach is not unreasonably costly and will prudently prevent unnecessary exposure to airborne lead." ${ }^{65}$ Indeed, as Robert Percival and his co-authors have noted, "[c]osts . . were projected to be less than 0.1 cent per gallon refined, adding only between $\$ 82$ million and $\$ 133$ million to the total of $\$ 1.5$ billion the industry was to invest in refining capacity through the year 1980."

In a hard-fought court battle, the industry tried to resuscitate the Kehoe rule, arguing that the EPA should not be allowed to regulate unless it could prove that leaded gasoline had caused actual harm in the past. ${ }^{67}$ Nonetheless, the EPA's new restrictions on leaded gasoline were upheld. ${ }^{68}$ The court's ultimate holding in the case is considered a landmark in U.S. environmental law because it established that the EPA could act in a precautionary fashion, rather than waiting for scientific certainty about the harmfulness of a substance before acting. ${ }^{69}$ The EPA set its standards for

62. Control of Lead Additives in Gasoline, 38 Fed. Reg. 33,734 (Dec. 6, 1973).

63. In the early 1970 s virtually all gasoline was leaded, with an average of 2.4 grams per gallon (gpg). The limit for 1979 at large refineries, and 1982 at small ones, was $0.5 \mathrm{gpg}$. See Nichols, supra note 19, at 50.

64. Robert V. Percival et al., EnVironmental Regulation: Law, Science, and POLICY 362 (4th ed. 2003).

65. Id. at $362 \mathrm{n} .42$.

66. $I d$.

67. See Ethyl Corp. v. EPA, 541 F.2d 1, 12 (D.C. Cir. 1976) (en banc) (affirming that the EPA may show a significant risk of harm rather than the heightened standard of proving actual harm).

68. See id. at 7 (finding that the Administrator of the EPA properly interpreted the statute and that the evidence offered during the rulemaking proceeding supported the final determination).

69. See generally Frederick R. Anderson et al., EnVIronmental Protection: LAW \& POLICY 409 (3d ed. 1999). 
lead based on the goal of protecting children from lead exposures that would harm their health and cognitive development. ${ }^{70}$

\section{NHANES and Needleman}

Around the same time that the EPA's initial lead phase down was taking effect, additional evidence of the wisdom of the EPA's actions was accumulating.

The little-remarked National Health Survey Act of 1956 required periodic national surveys of the population's health. ${ }^{71}$ This statute, also enacted without reliance on cost-benefit analysis, led to a national study in 1976-80 of children's blood lead levels. ${ }^{72}$ The National Health and Nutrition Examination Study-called NHANES II because it was the second of its kind-showed marked decreases in children's blood lead levels in the period examined. ${ }^{73}$ Because this period coincided with the implementation of the EPA's reduction of lead in gasoline, it was possible to study the relationship between the reduced blood lead levels found in NHANES II and the reductions in leaded gasoline required by the EPA. The relationship turned out to be remarkably consistent: children's blood lead levels declined in direct proportion to the reduction of lead in gasoline. ${ }^{74}$ This relationship became a cornerstone of the EPA's 1980s-era economic analysis of requiring further reductions in the lead content of gasoline.

During the same time, Herbert Needleman published his path-breaking study demonstrating a link between children's blood lead levels and IQ. ${ }^{75}$ The study answered the question that had dogged lead researchers for decades: even if blood lead levels were higher than they naturally would be, was this causing any harm? Needleman's answer was an emphatic yes. Needleman's study also made it possible to state, in quantitative terms, the effect of reducing blood lead levels on human health and well being. ${ }^{76}$

70. Regulation of Fuels and Fuel Additives, supra note 57, at 1258-59 (emphasizing that airborne lead exposure contributes to the abnormally elevated blood levels in urban adults and children).

71. See 42 U.S.C. $\S 241$ (2000).

72. See The Second National Health and Nutrition Examination Survey, Hematological and Nutritional Biochemistry Reference Data for Persons 6 Months-764 Years of Age: United States, 1976-80, available at http://www.cdc.gov/nchs/about/major/nhanes/nh2rrm. htm (last visited Jan. 9, 2005).

73. Id.

74. See Environmental Protection agency, Great lakes Binational toxics STRATEGY, DRAFT REPORT ON ALKYL-LEAD: SOURCES REGULATIONS AND OPTIONS, available at http://www.epa.gov/grtlakes/bns/lead/steplead.html (last visited Dec. 16, 2004).

75. See H.L. Needleman et al., Deficits in Psychologic and Classroom Performance of Children with Elevated Dentine Lead Levels, 300 NEW ENG. J. MED. 689, 689 (1979) (adding that the children with high lead levels performed worse than children with low lead levels in verbal tests, auditory and speech processing).

76. See $i d$. at $692-93$ (providing quantitative data on lead's effect on verbal processing 
Unfortunately, Needleman suffered the same fate as other lead researchers before him who had dared take on the lead industry. Researchers funded by the lead industry challenged his work, going so far as to press a formal charge of scientific misconduct with the National Institutes of Health. ${ }^{77}$ As Needleman stated in later years, after he had been completely exonerated, "[i]f you ever want to be intensively peer-reviewed, just produce a study with billions of dollars of implications and you will be reviewed to death." 78

Meanwhile, the lead industry was also active on another front: with President Ronald Reagan's election in 1980 after campaign promises to make government smaller, arguments in favor of relaxing the requirements for lead in gasoline suddenly gained a more sympathetic hearing. At this point, cost-benefit analysis did play a useful supporting role in helping Congress and sympathetic administrators to uphold the previous commitment to removal of lead from gasoline, despite the wavering of top Reagan appointees.

\section{Gorsuch Winks}

A month after taking office, President Reagan formed the "Task Force on Regulatory Relief," headed by Vice-President George H.W. Bush. The ostensible purpose of the Task Force was to coordinate actions among the various executive agencies and also to oversee compliance with Reagan's brand-new Executive Order 12291, requiring agencies to conduct costbenefit analyses for significant new regulatory initiatives. ${ }^{79}$ The real aim of the Task Force was to reduce regulation any way possible. ${ }^{80}$

One of the first actions to come within the sights of the Task Force was the EPA's lead phase down. ${ }^{81}$ The phase down was nearly, but not quite, complete: although the EPA had required large refineries to meet its new limits by 1979 , small refineries were given until 1982 to do so. ${ }^{82}$ In 1982 , following a Task Force recommendation, EPA not only proposed to delay

and IQ, and comparing the manner in which teacher's rate the behavior of children with high and low blood lead levels).

77. See Devra Davis, When Smoke Ran Like Water: Tales of Environmental DECEPTION AND THE BATtLe Aganst Pollution 128 (Basic Books 2002) (observing "[i]t was not known then that their [Needleman's accusers] work was supported by the lead industries").

78. Id. at 127.

79. See Press Release, Office of the Press Secretary to the Vice-President, Statement of the Vice-President Regarding an Executive Order Signed Today by the President Concerning Regulatory Management (Feb. 17, 1981), at http://www.thecre.com/ombpapers /Reagan. htm. (last visited Dec. 16, 2004).

80. See Erik D. Olson, The Quiet Shift of Power: Office of Management \& Budget Supervision of Environmental Protection Agency Rulemaking Under Executive Order 12,291, 4 VA. J. NAT. RESOURCES L. 1, 43 (1984).

81. See DAVIS, supra note 77, at 130.

82. See Control of Lead Additives in Gasoline, supra note 62, at 33,740. 
the requirement for small refineries, ${ }^{83}$ but also invited public comment on whether to relax the requirements for large refineries as well. ${ }^{84}$

Reagan's EPA Administrator at the time, Ann Gorsuch, appears to have been on the same page as the Task Force. During a meeting with Ethyl representatives, she was asked whether she would enforce the existing rules to phase down lead. Her reported response: she winked. ${ }^{85}$

Nevertheless, the public outcry over news that the phase down might be weakened made the EPA back off from its proposals. Eventually, the 1970 s-era rules were tightened rather than relaxed, ${ }^{86}$ and a federal court upheld the new rules almost in their entirety, even going so far as to opine that a complete ban on lead in gasoline would be justified. ${ }^{87}$

By March 1983, Gorsuch had resigned amidst a scandal arising out of the Superfund hazardous waste program. One EPA official was sent to jail for lying to Congress about the matter. ${ }^{88}$ Over a thousand EPA employees had lost their jobs early on in the Reagan administration, ${ }^{89}$ and the remaining employees' morale had hit an all-time low. It was time to restore credibility to the embattled agency.

\section{Ruckelshaus and Cost-Benefit to the Rescue}

Just weeks after Gorsuch resigned, EPA's first Administrator, William Ruckelshaus, returned to the agency in its time of need. One of his stated aims was to restore rigorous analysis and to displace the political forces that had recently dominated the agency's actions. ${ }^{90}$ Alvin Alm, his deputy, later recalled that at the time the agency was "really in need of some help," and that the agency's new leaders needed to "creat[e] confidence that we were getting work done." 91

It is only at this late date in the story that cost-benefit analysis made its famous, and helpful, appearance. Within six months of the regime change at the agency, Alm asked EPA's economics office (the Office of Policy, Planning and Evaluation) to put together a preliminary cost-benefit analysis

83. See Fuel and Fuel Additives; Proposed Suspension of Compliance Date for Small Refineries, 47 Fed. Reg. 7814 (Feb. 22, 1982).

84. Regulation of Fuel and Fuel Additives, 47 Fed. Reg. 7812 (Feb. 22, 1982).

85. See DAVIS, supra note 77, at 130.

86. See Nichols, supra note 19 , at 50-52.

87. See Small Refiners Lead Phase-Down Task Force v. EPA, 705 F.2d 506, 531 (D.C. Cir. 1983).

88. See DAVIS, supra note 77 , at 130.

89. Id.

90. See W.D. Ruckelshaus, Science, Risk, and Public Policy, 221 ScI. 1026 (1983).

91. For the oral history of Alvin Alm, see Environmental Protection Agency, EPA History, at http://www.epa.gov/history/publications/alm/21.htm (last visited Nov. 13, 2004); see also Environmental Protection Agency, EPA History, at http://www.epa.gov/history/ publications/alm/22.htm (last visited Nov. 12, 2004). 
of further regulation of lead in gasoline, including an outright ban. ${ }^{92}$ As Albert Nichols, who became intimately involved with the eventual analysis, recalled, Alm became interested in reviving the lead issue because of a remark by a lobbyist for the ethanol industry (ethanol was a potential substitute for lead), ${ }^{93}$ and also because "lead appeared to offer an opportunity to demonstrate that the risk management principles being promoted by Administrator William Ruckelshaus and Alm were not just a sophisticated way of saying 'no' to proposed regulations; they also could help identify cases in which additional regulation was justified." 94

Although Albert Nichols' account of the EPA's decision to do a costbenefit analysis of further lead reductions states that EPA "was not under significant pressure from... environmental groups to take additional action," Nichols also acknowledges, in a footnote, that "[o]ther prominent environmentalists-such as Ellen Silbergeld of the Environmental Defense Fund had been active for many years in efforts to reduce lead." 96 Others recall a more prominent role for environmental groups, in particular the Environmental Defense Fund, in persuading EPA to take another look at lead. Robert Percival, now a professor of law at the University of Maryland but then a young attorney at the Environmental Defense Fund, suggested during a meeting with Alvin Alm in the fall of 1983 that the EPA undertake a cost-benefit analysis of phasing out lead from gasoline. ${ }^{97}$ Several years later, Alm wrote that one of EPA's most important achievements - the 1980s-era phase down of lead in gasoline- had "come about through a chance encounter" with someone he did not know, who had suggested doing a cost-benefit analysis of further lead regulation. ${ }^{98}$

Whatever the origins of Alm's request, EPA's analysts complied, producing a cost-benefit analysis clearly demonstrating that additional regulation of leaded gasoline was amply justified in economic terms. Armed with this analysis, the EPA not only upheld the original rule, but adopted a new rule in 1985 that went much farther, requiring the removal by 1988 of about 90 percent of the lead that was still allowed in gasoline under the 1970 s rule. ${ }^{99}$ By this time, EPA felt confident enough to be able

92. Nichols, supra note 19 , at 53.

93. Id.; see also personal communication between Lisa Heinzerling and Joel Schwartz (Mar. 4, 2004) (source of specific reference to the ethanol lobbyist).

94. Nichols, supra note 19 , at 53.

95. Id. at 52-53.

96. Id. at $83 \&$ n.1.

97. Email from Bob Percival to Lisa Heinzerling (Mar. 15, 2004) (on file with authors).

98. Alvin Alm, The Multimedia Approach to Pollution Control: An Impossible Dream?, MUlTimedia APPROACHeS to POllution CONTROL: SyMPOSIUM PROCEedINGS 114, 115 (Nat'l Research Council 1987).

99. Under a new method of calculation, the lead level allowed under the 1973 rule was now measured as $1.1 \mathrm{gpg}$ (corresponding to $0.5 \mathrm{gpg}$ under the old method, as cited in note 41 , supra). See Nichols, supra note 19, at 51-52. The 1985 rule required reduction to 0.1 
to include in its final economic analysis enormous benefits from reducing blood pressure in men through phasing out lead in gasoline. These benefits alone, the EPA predicted, would be about ten times higher than the total costs of the rule by the late 1980 s. $^{100}$

\section{Crunching the Numbers}

The second wave of reduction of lead in gasoline, required by the EPA in the $1980 \mathrm{~s}$, is the example widely touted as evidence that cost-benefit analysis is a neutral decisionmaking tool, tilting in favor of neither regulation nor laissez faire.

However, the cost-benefit analysis performed by the EPA in the $1980 \mathrm{~s}$ could not have been performed if the regulation of the 1970s, the ensuing "first wave" removal of roughly 80 percent of the lead in gasoline, and the government-sponsored national survey of blood lead levels had not already occurred. EPA's cost-benefit analysis depended crucially on evidence gained from the studies showing a strong relationship between reduction of lead in gasoline and reduction in blood lead levels in children. This evidence was available only because regulation had already achieved such a substantial reduction of lead in gasoline. It is indeed useful that the lead cost-benefit analysis helped to prevent backsliding in the early years of the Reagan administration, and even justified the rapid removal of most of the remaining lead from gasoline. But this is very different from doing the job alone, or even playing the leading role.

Moreover, the story of cost-benefit analysis in supporting lead regulation stands almost alone: it is so universally cited that a skeptical observer might ask, is there a second example of cost-benefit methods being used to support environmental protection? According to participants in the studies, the cost-benefit analysis of leaded gasoline and the subsequent study of lead in drinking water (done just a few years later by the same analysts, using much of the same data) were "anomalous" successes, drawing on unusually strong data sets and enjoying a clear mandate from above to support protective regulations. ${ }^{101}$ Normally, of course, it is not possible to remove most of a pollutant from the environment, in order to develop the data supporting the removal of the remainder. And the political and administrative support for regulation that existed when Ruckelshaus returned to the EPA in the mid-1980s has been sadly lacking in the opening years of the twenty-first century. ${ }^{102}$

gpg under the new method of calculation. See id. at 57-62.

100. Id. at 74 tbl.3.

101. Ronnie Levin, Lead in Drinking Water, in ECONOMIC ANALYSES AT EPA, supra note 15 , at 230 .

102. See, among many other sources, Robert S. DEVINE, Bush Versus the ENVIRONMENT (Anchor Books 2004). 
In different hands, with a different political agenda, the cost-benefit analysis of lead regulation could have looked quite different. Recently, one prominent regulatory analyst has shown how this might have happened. Randall Lutter, formerly at OMB and now chief economist at the Food and Drug Administration (FDA), was, between government jobs, ensconced at the American Enterprise Institute, where he frequently wrote on the supposed dangers of over-protection against hazardous substances. Regarding lead, Lutter proposed to rethink the approach to the benefits of lead reduction. Rather than indirectly valuing the immense health improvements and the gains in children's IQ that have been traced to lead reductions, as EPA has done, Lutter argued that society should not value lead removal any more highly than individuals do. ${ }^{103}$ Moreover, he suggested that individual valuations could be determined from studying what parents spend on a medical treatment called chelation therapy to lower their children's lead levels. Since chelation is proven to work only for very high levels of lead poisoning, ${ }^{104}$ there is, unsurprisingly, little evidence that people choose to spend money on it for more common, chronic low-level lead problems. Applying the chelation yardstick, Lutter found that the EPA had overstated the benefits of lead reduction, perhaps by as much as eight-fold. ${ }^{105}$ In Lutter's view, therefore, less protective expenditure would be warranted-and the historic role of cost-benefit analysis in supporting lead reduction could have been less important.

Thus, it is not only the strong data and robust empirical studies that allowed cost-benefit analysis to support environmental protection in this case. Also crucial was the political support for a methodology that valued benefits relatively expansively. A different methodology, like Lutter's, could point in the opposite direction. The use of cost-benefit analysis by an Administration hostile to environmental protection will almost certainly not produce the equivalent of another lead phase down.

\section{DAMMING THE GRAND CANYON}

Leave it as it is. You cannot improve on it. The ages have been at work on it, and man can only mar it. ... What you can do is to keep it for your children, your children's children, and for all who come after you, as one

103. Randall Lutter, Valuing Children's Health: A Reassessment of the Benefits of Lower Lead Levels (AEI-Brookings Joint Ctr. for Regulatory Studies, Working Paper 00-02, 2000), available at http://www.aei.brookings.org/publications/working/working0002.pdf. (last visited Jan. 10, 2005).

104. See American Medical association, Report 6 of the Council on Scientific AfFAIRS: LeAd PoISONING AMONG CHILDREN (Dec. 1994), available at http://www.amaassn.org/ama/pub/category/13681.html (last visited Jan. 10, 2005).

105. Lutter, supra note 103 , at 6. 
of the great sights which every American if he can travel at all should see. ${ }^{106}$

What's so special about the Grand Canyon anyway? ${ }^{107}$

The water wars of the arid American West have transformed the natural landscape. With the help of countless billions of public dollars, the region's meager supplies of water have been rerouted to allow agriculture, industry, and residential development to flourish on barren desert lands, as described by Marc Reisner in his classic account, Cadillac Desert. ${ }^{108}$ At times, the "water wars" have almost ceased to be metaphorical. In 1934, Arizona mobilized its National Guard in an attempt to stop construction of a dam that would divert Colorado River water into California. ${ }^{109}$

In the 1960s, collateral damage in the water wars nearly claimed parts of the Grand Canyon, as huge dams were proposed on the Colorado River, just above and below the national park. ${ }^{110}$ The dams were defeated in part by the massive opposition organized by the Sierra Club and other environmentalists - and in part by an influential cost-benefit analysis performed by RAND Corporation economists, showing that the economic benefits of the dams were slightly less than the costs.

This could be considered a triumph for the environmentally benign use of cost-benefit analysis, except for one drawback: the RAND analysis is, in retrospect, absurd. The same methodology combined with better information, which became available just a few years later, would have led to the opposite conclusion and firmly endorsed the dams.

\section{Razing Arizona}

The Colorado River is one of the few major sources of water in Arizona, skirting the northern and western edges of the state. Most of the agriculture, industry, and people in Arizona are hundreds of miles away, many of them in and around Phoenix and Tucson, and separated from the river by mountains as well as desert. The proposed damming of the Grand Canyon arose as part of the Central Arizona Project (CAP), a colossal scheme to move water from the river to the people. ${ }^{111}$

106. President Theodore Roosevelt, Speech at the Grand Canyon (May 6, 1903), quoted in http://www.theodoreroosevelt.org/kidscorner/Grand_Canyon.htm (last visited Jan. 3, 2005).

107. Videotape: Grand Canyon, The Price of Power (The Sierra Club 1992), quoted in Clayton L. Riddle, Protecting the Grand Canyon National Park from Glen Canyon Dam: Environmental Law at its Worst, 77 MARQ. L. REV. 115, 115 (1993).

108. Marc ReIsner, Cadillac Desert: The AMERICAN West and ITS DisapPEaring WATER 2, 2-3 (Viking Penguin 1986). Except as otherwise noted, Reisner is the source for the following account of the Central Arizona Project and related background information.

109. Id. at 267-68.

110. Id. at 283.

111. See supra note 108. 
After decades of battles in the courts and in Congress (as well as the armed confrontation at the riverbank in 1934), Arizona finally won a legal entitlement to a significant share of the Colorado River's water in the early 1960s. This cleared the way for the Central Arizona Project, proposed years earlier, to proceed. However, the effort needed multi-billion-dollar financing to build its enormous aqueducts, and huge amounts of energy to pump the water up over the mountains. ${ }^{112}$

The Bureau of Reclamation, the federal agency that dammed so many western rivers, had been "solving" problems like this since the 1940s. Its preferred method was called "river-basin accounting," treating the development of a river and related waterworks as a single project. Profitable dams could be built on fast-flowing rivers, generating hydroelectric power that would finance money-losing irrigation and water diversion schemes, as well as powering the massive pumping stations required to move the water. If the projects in a river basin were unbundled, the logic of the market might dictate building the dams but skipping the irrigation and other unprofitable pieces of the picture. However, the federal government repeatedly bought the whole package deal, as the New Deal enthusiasm for big public construction projects meshed with the local interests of Western politicians-many of them ideologically opposed to expensive public-sector initiatives that benefited anyone else. ${ }^{113}$

By the time the Central Arizona Project began, most of the best sites on the Colorado had been taken for earlier developments. The only remaining options for big, profitable "cash register dams" that would finance the project were the Marble Gorge (or Marble Canyon) Dam and the Bridge Canyon Dam, later renamed Hualapai Dam to "honor" a Native American community. Marble Gorge, just upstream from the Grand Canyon National Park, would have flooded the Inner Gorge, essentially the first 40 miles of the river's course through the canyon. Hualapai, downstream from the National Park, would have created a 94-mile-long reservoir, entirely flooding the Grand Canyon National Monument and extending 13 miles into the National Park itself. ${ }^{114}$

Both dams were included in the revised CAP proposal, launched in 1963. In support of the proposal, the Bureau of Reclamation performed an economic analysis comparing the dams to thermal (fossil fuel) power plants; the result was that the dams were much cheaper, with benefit/cost ratios of 2.0 and $1.7 .^{115}$ These numbers emerged from a variant of cost-

112. See supra note 108 .

113. See REISNER, supra note 108 , at 267-68.

114. See supra note 108.

115. See Alan Carlin, The Grand Canyon Controversy: Lessons for Federal Cost-Benefit Practices, 5 tbl.1 (RAND Corp. 1967) [hereinafter Lessons for Federal Cost-Benefit Practices] (citing United States Department of the Interior, Bureau of Reclamation, "Pacific 
benefit analysis that is common in evaluation of power plants. The analysis assumed that if the dams were not built, something else would have to be built to generate the same amount of electricity. Thus the "benefit" of building the dams is that it would avoid the construction of the next-best alternative-which was a thermal power plant, according to the Bureau of Reclamation. A benefit/cost ratio of 2.0 for a dam means that the "benefit," i.e., the avoided cost of an equivalent power plant, is twice the cost of the dam.

In the Bureau's analysis, almost nothing was said about recreational benefits, and no mention was made of the value of the existence of the Grand Canyon per se (what environmental economists now call "existence value" or other varieties of "non-use value"). The analysis simply compared the two methods of generating electricity. Although referred to at the time as a cost-benefit analysis, this might be better described as a cost-effectiveness analysis, seeking the minimum-cost way to meet the goal of generating a fixed amount of electricity. ${ }^{116}$ The Bureau's result, strongly favoring the dams, is not a surprising one. Hydroelectric facilities built at places where large rivers are flowing rapidly downhill-like the Marble Canyon and Bridge Canyon sites-are routinely among the lowest-cost sources of electricity. If nothing of importance is lost due to the creation of the reservoir or other changes in river flow, hydroelectric development on fast-flowing major rivers is frequently a profitable way to generate electric power.

Yet many people naturally felt that something of great importance would be lost. The Sierra Club quickly organized widespread, vocal opposition to the dams, easily winning the war for public opinion. Defenders of the dams suggested that the elevated water level of the Hualapai reservoir would allow more visitors to see the canyon from tour boats; the Sierra Club asked if we should also flood the Sistine Chapel so that tourists could get closer to the ceiling. ${ }^{117}$ Soon thereafter, the IRS revoked the Sierra Club's tax-exempt status. ${ }^{118}$

Southwest Water Plan, Supplemental Information, Report on Marble Canyon Project, Arizona," Jan. 1964, p. 24); see also United States Department of the Interior, Bureau of Reclamation, "Pacific Southwest Water Plan, Supplemental Information Report on Bridge Canyon Project," Jan. 1964, p. 22.

116. The strength of cost-effectiveness analysis is that it avoids the problems of valuation of non-marketed benefits, such as the existence of the Grand Canyon; it only compares the market costs of alternative means of reaching a single, specified goal. The corresponding limitation is that cost-effectiveness analysis says nothing about the importance of its goal versus other goals. In the case of the Grand Canyon, the relative importance of generating electricity versus preserving the Canyon is the crucial omitted factor that led many people to reject the Bureau's analysis.

117. REISNER, supra note 108, at 296.

118. See id. at 297. 


\section{Too Cheap to Meter}

After four years of debate, the dams were defeated in 1967. While love of nature in general and the Grand Canyon in particular played an essential role, the Sierra Club and other opponents of the dams did not win on environmental arguments alone. Also crucial to the outcome was a rival cost-benefit analysis by two RAND Corporation economists, Alan Carlin and William Hoehn. ${ }^{19}$ Their work was publicized by the Sierra Club and by Congressional opponents of the dams; it was presented and debated at length in the Congressional hearings on the issue. ${ }^{120}$ Using a methodology much like the Bureau of Reclamation analysis, Carlin and Hoehn compared the dams to the cheapest alternative source of electricity; they again included almost nothing for the value of recreation, environmental amenity, or the existence of the Grand Canyon. But Carlin and Hoehn used a different alternative source of power as their benchmark. They compared the dams to nuclear power plants, which they believed to be astonishingly cheap.

Although their predictions of nuclear costs turned out to be hopelessly below the mark, Carlin and Hoehn did no worse than most people writing about nuclear power in the mid-1960s. At the time, nuclear power was a relatively new idea, still on the verge of commercial application. The hazards of nuclear power were not yet well known; the escalating costs of nuclear plants were not yet in sight. Instead, industry and government boosters of the new technology promoted the notion that nuclear energy would soon be "too cheap to meter." 21 A decade of intensive research and development in the 1950s, mostly government-sponsored, had led to the first orders for nuclear plants in the early 1960s-and to wild optimism

119. Lessons for Federal Cost-Benefit Practices, supra note 115, cites the original figures and presents intermediate revisions for Marble Canyon based on more reasonable assumptions about nuclear reactor operations. The final variant charged Hualapai, in particular, for the large water losses due to evaporation from its reservoir, and made other technical changes, as described by Alan Carlin \& William Hoehn in The Grand Canyon Controversy-1967: Further Economic Comparisons of Nuclear Alternatives (RAND Corp. 1967) [hereinafter Further Economic Comparisons]. The Carlin-Hoehn analysis was spelled out in a series of reports, all from RAND, including, in addition to the two just cited, Alan Carlin \& William Hoehn, Is the Marble Canyon Project Economically Justified? (1966) [hereinafter Marble Canyon Project]; Hoehn, What the Parsons Study Really Says About Nuclear Power Economics: The Grand Canyon Controversy, Round? (1967); and Carlin, The Grand Canyon Controversy or How Reclamation Justifies the Unjustifiable (1967) [hereinafter How Reclamation Justifies the Unjustifiable] (providing a retrospective on the controversy).

120. See the statements by Alan Carlin, and extensive discussion of his views, in the Hearing on the "Lower Colorado River Basin Project" of the Subcommittee on Irrigation and Reclamation of the US Senate Committee on Interior and Insular Affairs 1468-539 (1966).

121. Steven Mark Cohn, Too Cheap to Meter: An Economic and Philosophical ANALYSIS OF THE NUCLEAR DREAM 107 (State Univ. of N.Y. Press 1997). 
about the future of the technology. ${ }^{122}$ Almost half of the plants ordered during 1964-66, the years just before and during the Carlin-Hoehn analysis, were sold on fixed-price terms, with substantial subsidies from vendors seeking to increase their share of an exploding new market. ${ }^{123}$ The average plant being ordered in those years was more than three times the size of any that had yet been built, accompanied by exaggerated hopes about the declining costs that would come with growth. ${ }^{124}$

In 1967 the federal Atomic Energy Commission predicted that there would be 1,000 nuclear plants in operation by the year 2000, a prediction that turned out to be almost ten times too high. ${ }^{125}$ While 196 nuclear plants were ordered by electric utilities between 1967 and 1974, many of the later orders were cancelled. ${ }^{126}$ After 1974, the energy crisis led to an abrupt halt to the growth in demand for electricity, and hence diminished interest in building new plants. Meanwhile, the seemingly endless series of hazards, accidents, and near-misses at nuclear plants led to one expensive requirement for redesign after another. Each safety problem appeared to be controllable, at an additional cost-with the result that costs were steadily driven upward. ${ }^{127}$

A recent analysis of nuclear power offers a retrospective evaluation of early cost forecasts:

The magnitude of nuclear cost forecasting errors [before 1970] was extraordinary. Nuclear plants persistently cost about twice the inflation adjusted price predicted when they were purchased. The last forty-three plants coming on line in the U.S. (1983-present) cost ... more than six times the constant dollar sum projected in the mid-sixties, and generate electricity at . . more than five times the average rate predicted from $1963-1972 .{ }^{128}$

What the RAND analysis of the Grand Canyon essentially did was to compare the proposed dams to new reactors at 1960s fantasy prices. The result was that the reactors were slightly-not enormously-cheaper, so that the dams narrowly failed the cost-benefit test. In the first version of the Carlin-Hoehn analysis, the Marble Canyon dam had a benefit-cost ratio of 0.95 (that is, a reactor at fantasy prices was just five percent cheaper than the dam), while Hualapai had a ratio of 0.86 (a reactor beat this dam by 14 percent). ${ }^{129}$ Subsequent revisions lowered the ratios; in what appears

122. See id. at $46-47$.

123. See id. at $45-46$.

124. See id. at $45-47$.

125. See id. at 110.

126. COHN, supra note 121 , at 127 .

127. Id. at 93-95.

128. Id. at 104-05.

129. See Lessons for Federal Cost-benefit Practices, supra note 119, at 5 tbl.1 (documenting their original estimates). 
to be the final version, published after the dams had been defeated, the ratios were 0.76 for Marble Canyon and 0.61 for Hualapai. ${ }^{130}$

Even the Sierra Club was briefly disoriented by the mirage of the cheap nuclear alternative. As David Brower, the head of the Sierra Club at the time, stated in an interview recalling the battle over the Grand Canyon, "Alan Carlin, who was of the Rand Corporation, an economist, began to feed numbers into the system that were devastating. The principal argument that Larry Moss [a nuclear engineer working for the Sierra Club] was coming up with was we could go to nuclear instead. I was trapped in that briefly, but got out of that trap." "131 At the height of the debate, in the Sierra Club Bulletin of May 1966-described as the "Grand Canyon issue"-editor Hugh Nash wrote, in arguing against the dams:

Cheaper electricity is available from other sources... A nuclear power plant in New Jersey will produce power for 4 mills (compared with the dam's 5.3 mills) by $1969 \ldots$... Proponents of the dams try to make out that nuclear power is still pie in the sky. Not so. The TVA has contracted for a nuclear powerplant which ... will generate power for only 2.37 mills per kilowatt-hour. ${ }^{132}$

The RAND cost-benefit analysis involves many technical details; however, the decisive economic data are the capital costs of constructing the dams, on the one hand, and equivalent-sized nuclear plants, on the other. In each case the huge one-time costs are converted to annual charges, assuming that the construction costs will be paid back over the lifetime of the facility-just as a mortgage converts the one-time cost of buying a house to a series of payments over many years. In the RAND analysis, the "mortgage payments" on the construction cost amount to twothirds or more of the annual cost of owning and operating either the dams or the nuclear plants.

In the final revision of their analysis of the dams, Carlin and Hoehn estimated the capital cost of building the dams, in 2003 dollars, at a total of $\$ 4.27$ billion, or $\$ 2,186$ per kilowatt of electrical generating capacity. ${ }^{133}$

130. See supra note 111 .

131. Interview by Brad Dimock, Jeri Ledbetter, and Lew Steiger with David Brower, former Executive Director, Sierra Club, in 10 BOATMAN'S Q. REV. No. 3 (1997), available at http://www.gcrg.org/bqr/10-3/10-3bqr.htm (last visited Jan. 9, 2005).

132. Hugh Nash, Other Arguments Against Dams in Grand Canyon and Why Grand Canyon Should Not Be Dammed, 51 Sierra Club Bull. No. 5, 1966, at 5, 9. A mill is onetenth of a cent. Id. Assuming the quoted costs are in 1966 dollars per kilowatt-hour, and updating them with the consumer price index, the first two are equivalent to 2.3 cents per kilowatt-hour for nuclear power, compared with 3.0 cents for the dams, at 2003 prices. Id. The TVA nuclear cost is equivalent to 1.4 cents per kilowatt-hour at 2003 prices. Id. Nash and other Sierra Club writers, of course, spent much more time and effort on making the environmental case against the dams and describing their impact on the Grand Canyon. Id.

133. Further Economic Comparisons, supra note 119, at 15 tbl.2, 1.8, cols. 1 \& 3. The number in the text is a weighted average of the cost per kilowatt at each dam, weighted in proportion to their proposed capacities (1350 MW for Hualapai, $600 \mathrm{MW}$ for Bridge 
The capital cost of equivalent nuclear power plants, they thought, would be less than a third as much: about $\$ 1.3$ billion total, or a mere $\$ 665$ per kilowatt of capacity. ${ }^{134}$ The Carlin-Hoehn prediction of nuclear costs is very much in line with other forecasts from the mid-1960s, as seen in the graph, below. Forecasts from that era averaged $\$ 657$ per kilowatt, virtually identical to the Carlin-Hoehn guess. ${ }^{135}$ That is to say, the RAND study appeared to rely on the "sound science" of its day, but failed to notice-along with most of its contemporaries_that that "science" was unusually reliant on wishful thinking rather than hard data.

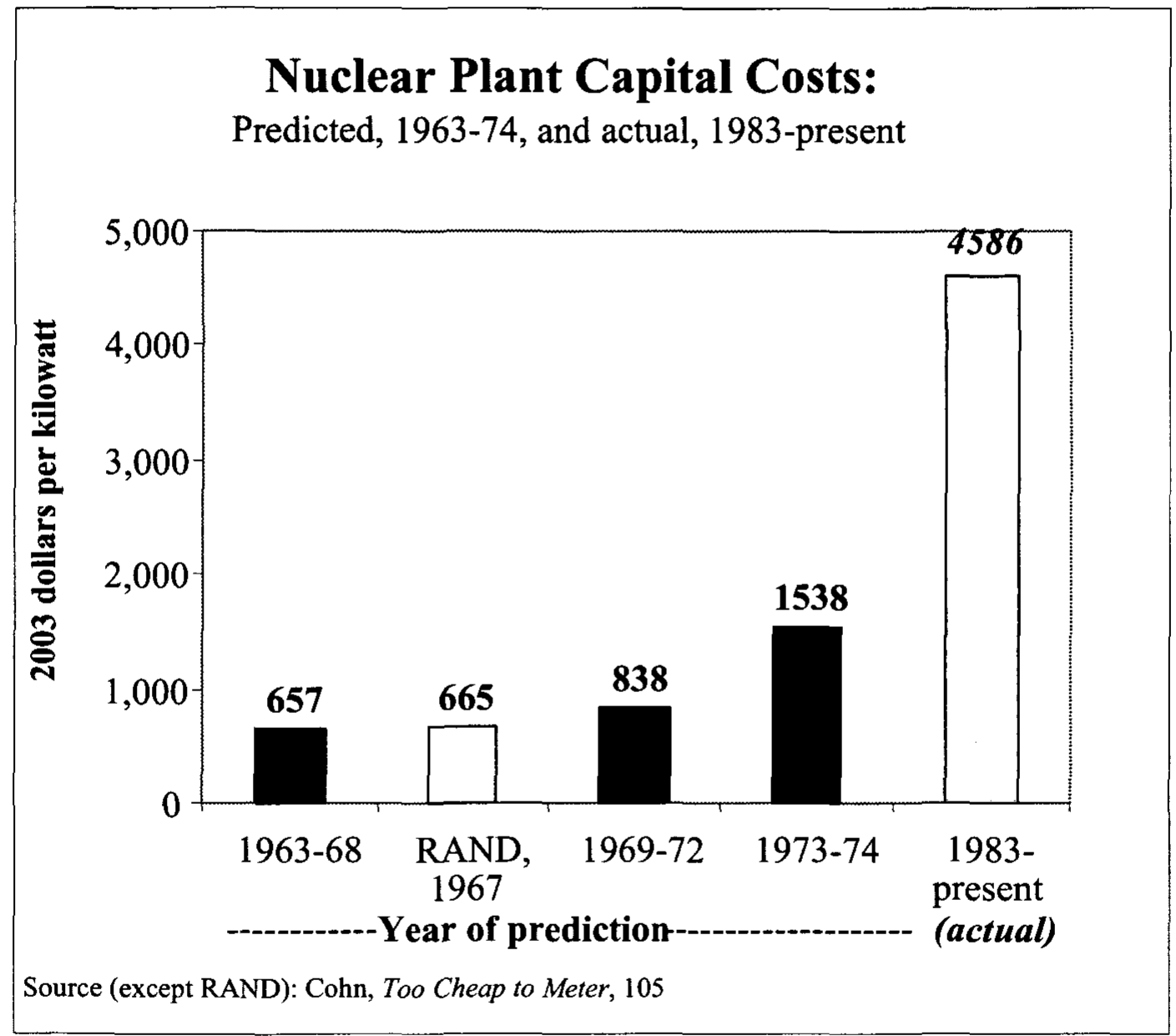

Canyon), converted from 1966 dollars to 2003 dollars using the GDP deflator. Id.

134. Id. at 15 tbl.2, notes to 1.1 , cols. 2 \& 4. Weighted average and conversion to 2003 dollars as in the previous note. Id. Although the construction costs were projected to be three times as large for the dams as for the nuclear plants, the benefit/cost ratios are not equally lopsided, both because the dams have lower operating costs, and because the dams would be expected to last longer and therefore could spread their capital costs out over many more years. Id.

135. Data in Figure 1, other than the RAND forecast, are from CoHN, supra note 121, at 105 tbl.4.3, converted to 2003 dollars using the GDP deflator as in the previous calculations. 
The analysis of the Grand Canyon occurred just before the rapid escalation in the costs of nuclear power. Between 1969-72, forecasts of nuclear costs rose more than 25 percent, to $\$ 838$ per kilowatt; ${ }^{136}$ even this moderate increase would have eliminated most or all of the projected economic advantages of nuclear power over the dams. Two years later, in 1973-74, forecasts of nuclear costs had jumped to $\$ 1538$ per kilowatt, more than double the mid-1960s level. ${ }^{137}$ Redoing the RAND analysis with this figure would clearly reverse the benefit/cost ratio. Consequently, using the cost estimates available six to eight years after the RAND study, the same methodology would end up agreeing with the Bureau of Reclamation (and common sense) that big dams are the cheapest way to generate electricity, if that is all that matters.

Furthermore, as the graph shows, nuclear costs continued to rise well beyond the level of the 1973-74 forecasts. The last plants completed those that came on line in 1983 or later-had average capital costs of $\$ 4,586$ per kilowatt, almost seven times the RAND estimate. ${ }^{138}$

\section{An Expensive Aqueduct Runs Through It}

The dams were defeated, but not the Central Arizona Project which they were supposed to finance. Indeed, the CAP was approved by Congress, without dams or other visible revenue sources, in $1968 .{ }^{139}$ The aqueduct is 336 miles long and 80 feet wide. ${ }^{140}$ Construction started in 1973 and finished in 1993 at a cost of over $\$ 4$ billion, of which $\$ 1.6$ billion will be paid back to the federal government by users over the first 50 years of operation. ${ }^{141}$ Unless water levels are above average, the Colorado River may not have enough water for all the commitments that have been made to Arizona, other states, and Mexico; the water that is supposed to flow through the expensive aqueduct may not always be there. ${ }^{142}$

As if taking the RAND analysis to heart, the huge Palo Verde nuclear plant was built in Arizona, planned within a few years of the defeat of the dams. ${ }^{143}$ Construction began in 1976 and finished in $1988 .{ }^{144}$ The cost,

136. CoHN, supra note 121, at 105 tbl.4.3. Data in Figure 1 has been converted to 2003 dollars using the GDP deflator as in the previous calculations.

137. Id.

138. Id. at 104. All costs cited here have been converted to 2003 dollars, so these increases are not due to inflation.

139. REISNER, supra note 108, at 300-01.

140. For a detailed description of the aqueduct, see the Central Arizona Project (CAP) website, at http://www.cap-az.com/faq (last visited Jan. 10, 2005).

141. For a detailed description of the CAP, see http://www.capaz.com/about/ index.cfm?action=history \& subsection $=5$ (last visited Jan. 9, 2005).

142. See CAP website, at http://www.cap-az.com/faq (last visited Jan. 9, 2005).

143. REISNER, supra note 108.

144. See information relating to the Palo Verde Nuclear Generation Station, at http://www.srpnet.com/about/stations/paloverde.aspx (last visited Jan. 10, 2005). 
according to the plant's operators, was $\$ 2608$ per kilowatt in 2003 dollars, or almost four times the RAND projection. ${ }^{145}$ At this price, needless to say, nuclear power was more expensive by far than the dams would have been, and also more expensive than the thermal power plants which the Bureau of Reclamation offered as the next-best alternative to the dams.

In the end, the Grand Canyon was preserved for future generations to see, as Theodore Roosevelt urged. In the more prosaic present, however, there were large numbers of people who wanted water and electricity provided in an inhospitable environment. Damming the Grand Canyon was unmistakably the cheapest, but not the best, way to provide these services to central Arizona. (Important questions about the wisdom, and the sustainability, of urban development in the midst of a desert lie just beyond the scope of this discussion.)

The RAND analysis that was instrumental in saving the Grand Canyon was right for the wrong reasons, erring spectacularly in favor of one environmental objective only by drastically underestimating another environmental problem. A cost-benefit analysis of the Grand Canyon performed today would include new categories of non-use value: What is the mere existence of the Grand Canyon worth to people who may or may not use or visit it? ${ }^{146}$ What is the value of the opportunity to pass it on to the next generation? ${ }^{147}$ Yet the calculation of huge existence values for unique natural wonders such as the Grand Canyon introduces a new set of problems into cost-benefit analysis. Estimates of these values differ widely, with similar survey questions about the dollar value of major national parks eliciting answers that differ by almost 100 to 1 between one academic study and the next. ${ }^{148}$ Existence values are important, but they do not bear much resemblance to prices; they are real, but "they are not really numbers." 149

If you support the preservation of the Grand Canyon, how would you react to a study showing that the benefits of the Canyon, including its existence value to the American people, were 20 percent lower than the benefits of damming it for hydroelectric development? Would you accept this as scientific proof that the Grand Canyon should in fact be dammed, despite your personal preferences? Or would you insist that the value of its

145. Id. The construction reportedly cost $\$ 5.9$ billion. Id. The plant's capacity is 3810 MW, implying an average cost of $\$ 1549$ per kilowatt. Id. Because construction began in June 1976 and ended in January 1988, it seems likely that the construction cost is reported in mixed-year historical dollars, with an average vintage of about 1982. Id. In the text, the reported figure has been converted from 1982 to 2003 dollars using the GDP deflator. Id.

146. ACKERMAN \& HEINZERLING, supra note 1, at 176-77.

147. Id. at 178 .

148. V. Kerry Smith \& Laura L. Osborne, Do Contingent Valuation Estimates Pass a 'Scope' Test? A Meta-Analysis, 31 J. ENVTL. ECON. \& MGMT. 287, 291 (1996).

149. ACKERMAN \& HEINZERLING, supra note 1, at 178. 
existence must have been underestimated, because you know that it is worth more than that? The former answer is difficult to imagine, but the latter implies that there is no empirical information conveyed by estimates of existence value. Rather, existence values offer only an awkward translation of independently established conclusions into the artificially constrained language of economics.

The cost-benefit analysts of the 1960 s, of course, knew nothing about the theoretical dilemmas and measurement problems surrounding existence values. It is fortunate, in retrospect, that they knew equally little about the economics of nuclear power.

\section{VINYL CHLORIDE IN THE WORKPLACE}

There is little dispute that [vinyl chloride] is carcinogenic to man and we so conclude. However, the precise level of exposure which poses a hazard and the question of whether a 'safe' exposure level exists cannot be definitively answered on the record. Nor is it clear to what extent exposures can be feasibly reduced. We cannot wait until indisputable answers to these questions are available, because lives of employees are at stake. ${ }^{150}$

That some must die so that all can eat is one thing; that some must die so that all can have see-through food packaging is another. ${ }^{151}$

Polyvinyl chloride, also known as vinyl or PVC, is a ubiquitous plastic, used in plumbing, siding, toys, medical equipment, and countless other products. ${ }^{152}$ Vinyl chloride, the chemical building block from which PVC is made, is a known human carcinogen. ${ }^{153}$ Since vinyl chloride can be emitted, either in plants where it is made or where it is used to make PVC, workers in those plants are at risk of hazardous exposures on the job. ${ }^{154}$

In 1974 the Occupational Safety and Health Administration (OSHA) adopted a strict new standard that sharply reduced allowable workplace

150. Standard for Exposure to Vinyl Chloride, Occupational Safety and Health Standards, 39 Fed. Reg. 35,890, 35,892 (Oct. 4, 1974) (codified at 29 C.F.R. pt 1910.1017).

151. David D. Doniger, Federal Regulation of Vinyl Chloride: A Short Course in the Law and Policy of Toxic Substances Control, 7 ECOLOGY L.Q. 497, 521 (1978), reprinted in David D. Doniger, The LaW and Policy of Toxic Substances Control 22 (Resources for the Future 1978).

152. See generally Frank Ackerman \& Rachel Massey, The Economics of Phasing Out PVC 1 (Global Development and Environmental Institute 2003), available at http://www.ase.tufts.edu/gdae/publications/articles_reports/index.html (last visited Jan. 10, 2005).

153. Pub. Health Serv., U.S. Department of Health and Human Services, National TOXICOlOgY Program, REPORT ON CARCINOGENS, 10th ed, at http://ehp.niehs.nih.gov/roc/tenth/intro.pdf (last visited Jan. 10, 2004).

154. See Michael S. Brown, Setting Occupational Health Standards: The Vinyl Chloride Case, in CONTROVERSY: Politics of TeChNiCal DeCisions 130-146 (Dorothy Nelkin ed., Sage Publications 1992). 
exposure to vinyl chloride. ${ }^{155}$ Consistent with its governing statute, the agency did not justify the rule on the basis of a cost-benefit analysis. Rather, the strict exposure limit was based on the level OSHA determined industry could meet-or, in the words of the statute, the "feasible" limit. ${ }^{156}$ The agency acted in response to a series of deaths attributable to vinyl chloride exposure, combined with disturbing new information on carcinogenicity of vinyl chloride in laboratory animals. OSHA acted on precautionary grounds, taking action when evidence of harm began to appear without waiting for precise, definitive quantification of the expected effects.

In the years since then, data have accumulated to confirm the toxicity of low doses of vinyl chloride, and on the range of organs affected by vinyl chloride exposures. These data have repeatedly confirmed the wisdom of OSHA's action. It is clear in retrospect that OSHA was right to regulate vinyl chloride exposure strictly. But what would have happened if OSHA had used cost-benefit analysis to make its decision, using the data that were available at that time? If performed in the manner favored today, such an analysis would have guided OSHA in the wrong direction, justifying little if any regulatory action.

\section{Incriminating Evidence}

Laboratory experiments documented the toxicity of vinyl chloride as early as 1925, and a range of adverse effects were documented in people in the 1930 s and 1940s. ${ }^{157}$ In the 1950s, Dow Chemical found that inhalation exposure to vinyl chloride damaged the liver and kidneys of laboratory animals; the company took steps to decrease employees' exposures, but did not inform them of the hazard. ${ }^{158}$ Two men died after acute inhalation exposure to vinyl chloride in $1960 .{ }^{159}$ In the mid-1960s, industry researchers found that many vinyl chloride workers suffered from a disease they named acroosteolysis-a painful and disabling disease affecting bones and connective tissue, especially in the hands. ${ }^{160}$ Industry worked actively to hide the link between vinyl chloride and acroosteolysis from the public. $^{161}$

The industry had established its own standard for vinyl chloride exposure in 1954, limiting the "time-weighted average" over the course of a work day to 500 parts per million ( $\mathrm{ppm}$ ), but allowing short-term

155. Standard for Exposure to Vinyl Chloride, supra note 150, at 35,892.

156. 29 U.S.C. $\$ 655$ (b)(5) (2000).

157. Brown, supra note 154, at 134.

158. Id.

159. Id. at $134-35$.

160. Id. at 135 .

161. MARKOWITZ \& ROSNER, supra note 27 , at 176-77. 
exposures above that limit. ${ }^{162}$ In 1967 , as evidence of the hazards of vinyl chloride continued to grow, industry lowered its standard to a $200 \mathrm{ppm}$ time-weighted average, and $500 \mathrm{ppm}$ absolute exposure limit. ${ }^{163}$ OSHA, which was founded in 1970, initially adopted the industry standard for vinyl chloride in 1971; the agency's first review of the issue in depth came in $1974 .^{164}$

As evidence about the effects of vinyl chloride on human health accumulated, one uncommon form of cancer, angiosarcoma of the liver, was at the forefront. It is such a rare disease that in the 1970s there were only 20 to 30 cases per year of angiosarcoma in the United States. ${ }^{165}$ The disease is strongly associated with vinyl chloride exposure, occurring among PVC workers at 400 to 3,000 times the rate in the general population. ${ }^{166}$ In January 1974, B.F. Goodrich announced the death of three PVC workers from angiosarcoma of the liver. ${ }^{167}$ This disclosure tipped the balance, making it clear to regulators that workers were dying from vinyl chloride exposure.

At the same time, other serious evidence about the health effects of vinyl chloride was bursting into public view. Data linking vinyl chloride to cancers in laboratory animals were first presented at a conference in $1970{ }^{168}$ An Italian scientist, Perluigi Viola, published data in 1971 showing that rats exposed to high doses of vinyl chloride developed a variety of tumors. ${ }^{169}$ Meanwhile, another Italian researcher, Cesare Maltoni, had been hired by the European chemical industry to conduct additional tests on vinyl chloride. In 1972 he found that kidney and liver cancers appeared in laboratory animals exposed to $250 \mathrm{ppm}$ vinyl chloride-that is, at half the short-term exposure limit accepted at the time. ${ }^{170}$ The American and European industries entered a secrecy agreement to prevent public circulation of this new information. ${ }^{171}$ But more damaging information continued to appear. By the time of a public hearing held by OSHA in 1974, Maltoni presented evidence of carcinogenicity in animals exposed to levels as low as $50 \mathrm{ppm}$ of vinyl chloride. ${ }^{172}$

162. Id. at $170-71$.

163. OSHA Standards for Vinyl Chloride Plants Upheld, 5 ENVTL. L. REP. 10,042 (1975).

164. DONIGER, supra note 151 , at 45.

165. OSHA Standards for Vinyl Chloride Plants Upheld, supra note 163, at 10,042; Brown, supra note 152, at 130-46.

166. DONIGER, supra note 151 , at 31 .

167. Brown, supra note 152, at 130-46.

168. MARKOWITZ \& ROSNER, supra note 27 , at 181.

169. Id.

170. Id. at $182-83$.

171. Id. at $178-91$.

172. Id. at $178-91$. 
In response, OSHA issued an emergency standard in April 1974, requiring companies to keep vinyl chloride levels at or below $50 \mathrm{ppm} .^{173}$ OSHA then held hearings to determine what the permanent standard for occupational vinyl chloride exposure should be. The agency initially proposed a standard of "no detectable level" of vinyl chloride in air; industry vigorously opposed this proposal, arguing it would force factories to shut down. ${ }^{174}$ Over the course of the hearings, thousands of pages of testimony were submitted from industry, unions, and occupational health experts. Industry representatives argued that low levels of vinyl chloride exposure had not been demonstrated to harm human health, and that strict regulation of the carcinogen would put factories out of business. ${ }^{175}$ Labor and health advocates argued for stronger regulation. ${ }^{176}$ OSHA issued a permanent standard for occupational vinyl chloride exposure in October 1974 , setting a maximum allowable exposure level of $1 \mathrm{ppm}$ averaged over an eight-hour period. ${ }^{177}$ The standard was a slight retreat from the "no detectable level" proposal, in response to industry objections. ${ }^{178}$ However, $1 \mathrm{ppm}$ was the next-strongest vinyl chloride standard considered by the agency, and a huge improvement over previous standards.

\section{What OSHA Knew}

At the time of OSHA's decision, substantial incriminating evidence was available on the carcinogenicity of vinyl chloride, but many questions remained unanswered. OSHA's success in regulating vinyl chloride depended on the agency's willingness to take precautionary action in the face of uncertainty. Had the agency attempted to estimate a monetary value for the likely benefits of reducing vinyl chloride exposure, it would have had difficulty making the case for the regulation. Much of the information required for the "benefits" side of the balance sheet was simply unknown at the time of OSHA's decision.

For example, OSHA had no firm estimate of how many people had been or would be killed by angiosarcoma of the liver resulting from vinyl chloride exposure. There was not enough information available, either from the Italian studies or from the U.S. fatalities, to draw a dose-response curve. OSHA was aware of carcinogenic hazards to other organs, including the lung, kidney, brain and skin, as well as some non-cancer effects, ${ }^{179}$ but

173. See id. at 204.

174. See MARKOWITZ \& RoSNER, supra note 27, at 213.

175. Id. at 214.

176. See id. at 215-17.

177. See id. at 220.

178. See Thomas O. McGarity \& Sidney A. Shapiro, Workers at Risk: The Failed Promise of the Occupational Safety and Health Administration 39 (Praeger 1993).

179. Standard for Exposure to Vinyl Chloride, supra note 150, at 35,890-91. 
the agency possessed little epidemiological data on the relationship of these other disorders to vinyl chloride exposure in humans. ${ }^{180}$ The extent of OSHA's knowledge about the applicability of animal data to human health was also limited. ${ }^{181}$ It would not have been possible, in other words, to quantify the expected health impacts resulting from a given exposure level. Quantifying effects, however, is exactly what cost-benefit analysis requires. In the absence of hard estimates of the magnitudes involved, many benefits would typically be omitted from a cost-benefit analysis-in effect, valued at zero.

Although precise quantitative estimates of impacts were not available, important aspects of both laboratory (animal) and epidemiological (human) evidence were available to OSHA in 1974. Animal evidence available to OSHA at the time of the ruling included data from Cesare Maltoni and others showing high levels of cancer in laboratory animals exposed to concentrations as low as $50 \mathrm{ppm}$ of vinyl chloride. ${ }^{182}$ In one set of experiments, 200 mice were exposed to $50 \mathrm{ppm}$ of vinyl chloride in air for eleven months; half of them died. ${ }^{183}$ In short, the allowable exposure level established by OSHA's emergency action in early 1974 was still high enough to kill laboratory animals within months.

On top of the laboratory evidence, OSHA also knew that vinyl chloride workers were dying. There were at least 13 confirmed cases of angiosarcoma of the liver, which had led to deaths at B.F. Goodrich, Union Carbide, Firestone Plastics, and Goodyear Tire \& Rubber. ${ }^{184}$ In OSHA's view, the link between cancer and vinyl chloride was clear from these animal and human data. ${ }^{185}$

What OSHA did not have was any hard information on the effects of vinyl chloride exposure below $50 \mathrm{ppm}$. The industry presented arguments that an exposure threshold for tumor induction had been identified; OSHA discussed and rejected this view. ${ }^{186}$ Instead, OSHA's final ruling cited the conclusion of the Surgeon General's Ad Hoc Committee, which found that "safe exposure levels for carcinogenic substances cannot be scientifically determined," and noted that testimony provided by the National Institute for Occupational Safety and Health (NIOSH) also supported the view that no safe threshold could be defined. ${ }^{187}$ Retreating under industry pressure

180. See id. at 35,890 .

181. See id. at 35,891 .

182. See id.

183. See id. at 35,891 .

184. See id. at 35,890-91.

185. See Standard for Exposure to Vinyl Chloride, supra note 150, at 35,891.

186. See id. at 35,891-92.

187. Id. at 35,891 . 
from the "no detectable level" standard favored by NIOSH and others on scientific grounds, OSHA adopted the next-best option.

\section{Vinyl Chloride Since 1974}

In the years following OSHA's decision, scientists have continued to collect information on the health effects of vinyl chloride exposure, and have continued to document the growing numbers of people affected. For example, a 1976 article documented an increased likelihood of birth defects in populations living near vinyl chloride polymerization facilities. ${ }^{188} \mathrm{~A}$ 1977 article presented evidence suggesting that non-occupational exposure routes, such as living near a polymerization or fabrication plant, might also play a role in causing angiosarcoma of the liver. ${ }^{189}$ A 1980 review article found that research since the OSHA ruling had shown vinyl chloride to be carcinogenic to other organs, including the brain and lung. ${ }^{190}$ A 1986 article supported a link between vinyl chloride exposure and testicular damage in laboratory animals. ${ }^{191}$ An epidemiological study published in 1990 linked vinyl chloride exposure to human liver tumors other than angiosarcoma. ${ }^{192}$

In summary, since OSHA's 1974 ruling, the evidence on health hazards associated with vinyl chloride exposure has steadily mounted. In retrospect, we know that vinyl chloride exposure posed severe hazards to workersand the communities around the manufacturing plants-even at low doses. OSHA acted decisively on the incriminating information that was already available at the time of the ruling; subsequent history has shown that the costs of inaction would have been even higher than OSHA knew at the time. With this history in mind, in the next section we look at what might have transpired if OSHA had relied on formal cost-benefit analysis to arrive at its decision.

\section{Cost-Benefit Analysis}

If OSHA had used cost-benefit analysis to evaluate its options in 1974, what would the result have been? For cost-benefit analysis, we need dollar values. On the "cost" side, OSHA had access to a variety of estimates.

188. See Peter F. Infante et al., Carcinogenic, Mutagenic, and Teratogenic Risks Associated with Vinyl Chloride, 41 MUTATION RES. 131, 131-34 (1976).

189. See Judith Brady et al., Angiosarcoma of the liver: an epidemiologic survey, $59 \mathrm{~J}$. NAT'L CANCER INST. 1383, 1383-85 (Nov. 1977).

190. See Joseph K. Wagoner et al., Toxicity of vinyl chloride and polyvinyl chloride as seen through epidemiologic observations, $6 \mathrm{~J}$. TOXICOLOGY \& ENVTL. HEALTH 1101, 110107 (1980).

191. See Wenfang $\mathrm{Bi}$ et al., Effect of Vinyl Chloride on Testis in Rats, 10 ECOTOXICOLOGY \& ENVTL. SAFETY 281, 281-89 (Dec. 1985).

192. See R. Pirastu et al., Mortality From Liver Disease Among Italian Vinyl Chloride Monomer/Polyvinyl Chloride Manufacturers, 17 AM. J. INDUS. MED. 155, 155-61 (1990). 
Industry representatives had put forward several estimates of what it would cost to reduce workplace vinyl chloride exposure. In addition, OSHA commissioned an independent study, by the consulting firm Foster D. Snell, to gauge the likely costs of several regulatory options. ${ }^{193}$

OSHA's consultant analyzed the costs of several regulatory options, but did not produce estimates for the cost of the $1 \mathrm{ppm}$ standard that was ultimately adopted. For a somewhat looser standard, they estimated annual compliance costs of $\$ 109$ million. ${ }^{194}$ A widely cited account of the regulation, published in 1995 by the Office of Technology Assessment, says that the best information available to OSHA implied that the cost of the $1 \mathrm{ppm}$ standard would be $\$ 1$ billion. ${ }^{195}$ It appears likely that this is a total cost for conversion, not an annual cost. ${ }^{196}$ If so, it implies an annual compliance cost of roughly $\$ 200$ million. ${ }^{197}$ Had OSHA carried out a costbenefit analysis, we assume it would have relied on a figure of about $\$ 200$ million for annual costs.

At the time of the ruling, OSHA lacked much of the data on benefits that cost-benefit analysts would rely on today. The agency noted that about three-quarters of the employees with the highest vinyl chloride exposure had not been located; that the average latency period for development of liver cancers appeared to be 20 years; and that the dose-response relationship for angiosarcoma of the liver was not known. ${ }^{198}$ For all these reasons, there was no way to determine the total number of people who

193. Foster D. SNell, INC., ECONOMIC IMPACt Studies OF THE EFFECTS OF PRoposed OSHA STANDARDS FOR VINYL CHLORIDE (1974) [hereinafter SNELl STUDY]. This study was completed for the Occupational Safety and Health Administration, U.S. Department of Labor, Contract No. L/A 74-167. Foster D. Snell is a subsidiary of Booz, Allen, and Hamilton, Inc., Florham Park, NJ.

194. This is the sum of $\$ 22$ million a year in the vinyl chloride monomer industry, to reach a standard of $2-5 \mathrm{ppm}$, plus $\$ 87$ million a year to meet a $10-15 \mathrm{ppm}$ standard in the PVC industry. See JOHN M. MENDEloff, THE DilemMa OF TOXIC Substance REgulation: How OverREgUlation CAUSES UNDERREgulation AT OSHA 248 (MIT Press 1998).

195. Office of Technology Assessment, Gauging Control Technology and REGULATORY IMPACTS IN OCCUPATIONAL SAFETY AND HEALTH: AN APPRAISAL OF OSHA'S ANALYTIC APPROACH 89 (Washington, DC: US Government Printing Office, September 1995) (hereinafter OFFICE OF TECHNOLOGY ASSESSMENT].

196. The report by OSHA's consultants mentions, in a footnote, that one of the firms in the industry estimated that the total capital cost for trying to reach the "no detectable" level of vinyl chloride would be $\$ 856$ million. This number is the only source we have been able to locate for OTA's \$1 billion estimate (perhaps rounded off, or with operating costs added, to bring it up to $\$ 1$ billion). See SNELL STUDY, supra note 193, at Exhibit V-15, n.5; see also MENDELOFF, supra note 194, at 248 n.3 (breaking down the annual cost estimates into vinyl chloride monomer and polyvinyl chloride monomer sectors).

197. The SNELL STUDY, supra note 193, amortized capital costs over 10 years at $12 \%$. Applying this rule, the annual carrying cost for a $\$ 1$ billion investment would be $\$ 177$ million; for a $\$ 856$ million investment, the annual carrying cost would be $\$ 151$ million. Assuming that there are operating costs as well as capital costs for compliance, we obtain a very rough estimate of $\$ 200$ million per year.

198. See Standard for Exposure to Vinyl Chloride, supra note 150, at 35,891. 
would ultimately be affected. Evidence on other cancers or non-cancer diseases caused by vinyl chloride was even less complete. In many costbenefit analyses, benefits with such inadequate data are routinely ignored, on the grounds that they are impossible to quantify.

However, even in the absence of hard data on benefits, it is possible to do the calculation in reverse: What estimates would have been needed for the regulation to pass a cost-benefit test? The principal benefit is the reduction in deaths caused by vinyl chloride exposure; how many lives would OSHA have had to think it was saving in order to justify an annual cost of $\$ 200$ million? That is, if human lives were expressed as dollar values and placed on one side of the scale, how many lives would it take to balance out $\$ 200$ million in expenses for the industries using vinyl chloride?

The calculation can be done either with recent estimates of the dollar value of a life, or with the much lower estimates that were common back in 1974. The highest value of a life that has been widely employed for regulatory analysis is EPA's estimate of $\$ 4.8$ million in 1990 dollars, used in a number of decisions in the late $1990 \mathrm{~s} .{ }^{199}$ This value was based largely on statistical analysis of the wage differentials between slightly more and less dangerous jobs. Frequently the value of life has been adjusted to account for inflation; for example, in the arsenic cost-benefit analysis, completed in 2000, EPA adjusted the $\$ 4.8$ million figure up to the equivalent in 1999 dollars, or $\$ 6.1$ million. ${ }^{200}$ If this estimate is similarly adjusted back to 1974, the value of a human life in that year's dollars was $\$ 1.81$ million. Thus, to "break even" against a \$200 million cost in 1974 , OSHA's standard would have had to save about 110 human lives per year.

The revelations that spurred OSHA into action involved 13 cases of vinyl chloride workers who died of angiosarcoma. In retrospect, this is not an unreasonable estimate for the annual death rate from angiosarcoma of the liver caused by vinyl chloride exposure. ${ }^{201}$ It would have been impossible for OSHA to argue that more than 100 workers were dying of angiosarcoma each year; and data were not available on any other causes of death linked to vinyl chloride. Therefore, cost-benefit analysis would have

199. Since 2001, the Bush Administration has used different methodologies that lead to sharply lower values. See the discussion in ACKERMAN \& HEINZERLING, supra note 1, at 82.

200. National Primary Drinking Water Regulations: Arsenic and Clarifications to Compliance and New Source Contaminants Monitoring, Final Rule, 66 Fed. Reg. 6976, 6976-7012 (Jan. 22, 2001).

201. I.F.H. Purchase et al., Vinyl Chloride: An Assessment of the Risk of Occupational Exposure, 25 FD CHEM. ToxiC. 187-202 (1987). A total of 99 cases of angiosarcoma of the liver attributable to vinyl chloride were recorded from 1974 to 1982 , or 11 per year. Id. at 196. Due to the long latency period for developing angiosarcoma, more cases were expected to result from the high rates of exposure before 1974; this study predicts a cumulative total of 150 to 300 more cases. 
supported the industry contention that the benefits of strict regulation of workplace exposure did not justify the expense.

The above calculation is only one version of what a cost-benefit analysis might have looked like. Another variant would have argued even more strongly against the regulation. The crucial estimate of $\$ 1.81$ million per life is a modern figure transported back in time. At the time of the OSHA decision, in 1974, the wage-risk calculations used to value life in the 1990s were not yet widely accepted; much lower values of life were in use for cost-benefit calculations. In the infamous calculation in the Ford Pinto controversy, which occurred at about the same time, Ford's economists cited government agency estimates of the value of a life of only $\$ 200,000$, based largely on lost earnings. ${ }^{202}$ If OSHA had actually tried to do a costbenefit analysis in 1974, it might easily have ended up using the "Pinto value" of $\$ 200,000$ per life. With this value per life a regulation would need to save 1,000 human lives per year in order to break even against a $\$ 200$ million cost.

A total of about 1,500 workers were employed in vinyl chloride production in 1974, and about another 5,600 worked in PVC resin production, for a total of just over 7,000 in the affected industries. ${ }^{203}$ Thus to support OSHA's regulation with a cost-benefit analysis using the "Pinto value," it would have been necessary to show that one of every seven workers in the industry would have died from vinyl chloride exposure each year in the absence of regulation.

If the agency had discounted future benefits, the number of deaths required to support the regulation would have been even larger. The average latency period for angiosarcoma cases is about 20 years. ${ }^{204}$ If the value of a human life is discounted at a three percent discount rate over the average 20-year delay before the diagnosis of fatal cancer, then each life becomes worth only 55 percent as much: ${ }^{205}$ the $\$ 1.81$ million "modern value" drops to a present value of $\$ 1$ million, while the $\$ 200,000$ "Pinto value" shrinks to $\$ 110,000$. At these rates, about 200 deaths per year in the former case, or around 2,000 in the latter, would have to be averted in order for the policy to be worth its billion dollar price tag. A higher discount

202. E.S. GRUSH \& C.S. SAUNBY, Fatalities Associated with Crash-Induced Fuel Leakages and Fires, reprinted in THE FORD PINTO CASE: A STUDY IN APPLIED ETHICS, BUSINESS, AND TECHNOLOGY 171 (Douglas Birsch \& John H. Fielder eds., SUNY Press 1994).

203. Brown, supra note 152 , at 130-46.

204. See, e.g., Janet Kielhorn et al., Vinyl Chloride: Still $A$ Cause for Concern, ENVIRONMENTAL HEALTH PERSPECTIVES, July 2000, available at http://ehp.niehs.nih.gov/ docs/2000/108p579-588kielhorn/abstract.html (last visited Jan. 10, 2005).

205 . The present value of a benefit $B$, received 20 years from now, at a $3 \%$ discount rate, is $\mathrm{B} /(1.03)^{20}$, which is roughly equal to $0.55 \mathrm{~B}$. 
rate, which analysts commonly used at the time, ${ }^{206}$ would have reduced the present value of the fatalities even more, raising the number of averted deaths required to "justify" the regulation even farther beyond the bounds of plausibility. At a seven percent discount rate, the break-even number of avoided deaths is about 400 per year with the modern value of life, or 4,000 with the Pinto value. At a ten percent discount rate, the break-even point jumps to roughly 700 with the modern value, or 7,000-the entire workforce of the industry-with the Pinto value. That is, using a ten percent discount rate and the value of life estimated in the 1970s, it would be necessary to show that every worker in the industry, every year, would have died in the absence of the standard, in order to justify the regulation in cost-benefit terms.

The report by OSHA's consultants included estimated costs for more lenient standards, with ceilings of 10,25 , or $50 \mathrm{ppm}$ of vinyl chloride in the air. These would have required smaller, but still substantial, numbers of avoidable deaths to "justify" their adoption in cost-benefit terms. With the number of known deaths in the low two figures, cost-benefit calculations would indicate that even these standards were too expensive for the benefits that would be achieved.

\section{An Unexpected Bargain}

As it turned out, the advance estimate of the costs of reducing vinyl chloride exposure was just that: an estimate. Producers quickly adopted innovative technologies that made it much easier to limit vinyl chloride in air. A 1978 study estimated that the industry had spent only $\$ 20$ million per year-a tenth of the predicted value-on compliance in the four years since the rule was passed. ${ }^{207} \mathrm{~A}$ former economist at the Department of Labor concluded that the actual cost of complying with the standard was only seven percent of the predicted cost. $^{208}$ According to a later retrospective overview by the Office of Technology Assessment, the total cost of compliance with the regulation was about a quarter of what had been estimated, and none of the producers were driven out of the industry by regulatory costs. ${ }^{209}$ Whether the actual costs were seven percent, a tenth, or a quarter of the original estimate, it is clear that compliance costs were a fraction of the best guess OSHA was able to come up with in

206. See Lisa Heinzerling, Discounting Our Future, 34 LAND \& WATER L. REV. 39, $45-$ 46 (1999).

207. MENDELOFF, supra note 194, at 248 (citing HERBERT R. NORTHRUP ET AL., THE IMPACT OF OSHA 383-89 (Indus. Research Unit, Wharton Sch., Univ. of Pa. 1978)).

208. MCGARITY \& SHAPIRO, supra note 178, at 268-69 (citing Marguerite Connerton \& Mark MacCarthy, Cost-Benefit Analysis and Regulation: Expressway to Reform or Blind Alley? 21 (Center for National Policy 1982)).

209. See OFFICE OF TECHNOLOGY ASSESSMENT, supra note 195, at 89. 
advance. Meanwhile, our knowledge of the benefits continues to grow as the evidence accumulates on a wide variety of disorders associated with vinyl chloride exposure. OSHA did not know any of this at the time of the ruling; but its precautionary decision has been vindicated by the science, as well as the economic information, that has accumulated since 1974.

Cost-benefit analysis would have argued strongly against OSHA's prescient regulation; once again, it would have been wrong in retrospect.

\section{CONCLUSION}

If the EPA had been required to conduct a cost-benefit analysis before taking lead out of gasoline, the agency might never have acted. Ironically, that would have meant that the famous 1980 s cost-benefit analysis of removing lead from gasoline would never have happened either, because there would have been no data on falling levels of lead in children's blood. Likewise, cost-benefit calculations with realistic nuclear costs would have led the RAND analysts to the obvious conclusion that they happily and mistakenly missed: big dams are a very cheap way to generate electricity, if that is all that matters. And cost-benefit analysis would have shown that vinyl chloride regulation was too expensive for the benefits it produced. It would seemingly have been optimal, in cost-benefit terms, to have allowed more workers to die of cancer every year in order to have cheaper vinyl siding on the market.

Our country has enacted many farsighted, protective laws and regulations governing public health and the environment. Economic analysis has sometimes played an important supporting role in improving these regulations. But economics has not been the gatekeeper, allowed to make the final decision on which regulations will take effect and which will not. A rigid insistence on making regulations pass cost-benefit tests would, in retrospect, have gotten the wrong answer time after time. There is no reason to expect the same narrow methods to perform any better today. 